\title{
mTOR regulates GPVI-mediated platelet activation
}

\author{
Longsheng Wang ${ }^{1 \dagger}$, Gang Liu' ${ }^{1,5 \dagger}$, Nannan Wu ${ }^{1 \dagger}$, Baiyun Dai ${ }^{1}$, Shuang Han ${ }^{1}$, Qiaoyun Liu², Fang Huang ${ }^{2}$, \\ Zhihua Chen ${ }^{3}$, Weihong Xu', Dajing Xia ${ }^{2}$ and Cunji Gao ${ }^{1,6^{*}}$
}

\begin{abstract}
Background: Due to mTOR (mammalian/mechanistic target of rapamycin) gene-loss mice die during embryonic development, the role of mTOR in platelets has not been evaluated using gene knockout technology.

Methods: A mouse model with megakaryocyte/platelet-specific deletion of mTOR was established, and be used to evaluate the role of mTOR in platelet activation and thrombus formation.

Results: $\mathrm{mTOR}^{-/-}$platelets were deficient in thrombus formation when grown on low-concentration collagencoated surfaces; however, no deficiency in thrombus formation was observed when $\mathrm{mTOR}^{-/-}$platelets were perfused on higher concentration collagen-coated surfaces. In $\mathrm{FeCl}_{3}$-induced mouse mesenteric arteriole thrombosis models, wild-type (WT) and $\mathrm{mTOR}^{-1}$ - mice displayed significantly different responses to low-extent injury with respect to the ratio of occluded mice, especially within the first $40 \mathrm{~min}$. Additionally, $\mathrm{mTOR}^{-1}$ platelets displayed reduced aggregation and dense granule secretion (ATP release) in response to low doses of the glycoprotein VI (GPVI) agonist collagen related peptide (CRP) and the protease-activated receptor-4 (PAR4) agonist GYPGKF-NH 2 ; these deficiencies were overcame by stimulation with higher concentration agonists, suggesting dose dependence of the response. At low doses of GPVI or PAR agonist, the activation of $a_{\| b} \beta_{3}$ in $\mathrm{mTOR}^{-/-}$platelets was reduced. Moreover, stimulation of $\mathrm{mTOR}^{-1-}$ platelets with low-dose CRP attenuated the phosphorylation of S6K1, S6 and Akt Ser473, and increased the phosphorylation of PKC $\delta$ Thr505 and PKC $\varepsilon$ Ser729. Using isoform-specific inhibitors of PKCs $(\delta, \varepsilon$, and a/ $\beta)$, we established that PKC $\delta / \varepsilon$, and especially PKC $\delta$ but not PKCa/ $\beta$ or PKCO, may be involved in low-dose GPVI-mediated/ mTOR-dependent signaling.
\end{abstract}

Conclusion: These observations indicate that mTOR plays an important role in GPVI-dependent platelet activation and thrombus formation.

Keywords: Platelets, mTOR, GPVI, Dense granule secretion (ATP release), Pkc $\delta$

\section{Background and introduction}

At the site of an injured vessel, platelets are recruited and undergo rapid aggregation to form a hemostatic or thrombotic plug. After recruitment, subendothelial

\footnotetext{
*Correspondence: zjuc239@163.com

†Longsheng Wang, Gang Liu and Nannan Wu contributed equally to this work

${ }^{1}$ Chronic Disease Research Institute, Department of Nutrition and Food Hygiene, Zhejiang University School of Public Health, 866 Yu-Hang-Tang Road, Hangzhou 310058, China

Full list of author information is available at the end of the article
}

matrix collagen interacts with platelet surface glycoprotein VI (GPVI) and stimulates the platelets at the site of recruitment [1]. The process of platelet activation is complex and involves several pathways and signaling molecules, and there are a limited number of studies that directly demonstrate platelet-specific functions of key modulators using gene knockout technology [2].

Mammalian target of rapamycin (mTOR), also called mechanistic target of rapamycin, is a serine/threonine kinase that is expressed in megakaryocytes, proplatelets, and circulating platelets [3]. mTOR interacts

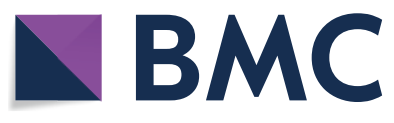

(c) The Author(s) 2021. This article is licensed under a Creative Commons Attribution 4.0 International License, which permits use, sharing, adaptation, distribution and reproduction in any medium or format, as long as you give appropriate credit to the original author(s) and the source, provide a link to the Creative Commons licence, and indicate if changes were made. The images or other third party material in this article are included in the article's Creative Commons licence, unless indicated otherwise in a credit line to the material. If material is not included in the article's Creative Commons licence and your intended use is not permitted by statutory regulation or exceeds the permitted use, you will need to obtain permission directly from the copyright holder. To view a copy of this licence, visit http://creativeco mmons.org/licenses/by/4.0/. The Creative Commons Public Domain Dedication waiver (http://creativecommons.org/publicdomain/ zero/1.0/) applies to the data made available in this article, unless otherwise stated in a credit line to the data. 
with other proteins and assembles into two complexes: mTOR complex1 (mTORC1) and mTOR complex2 (mTORC2). The upstream and downstream signals of these two complexes, as well as their sensitivities to rapamycin, are different. Rapamycin inhibits mTORC1, but not mTORC2, during acute treatment [4]; however, in some cell types, mTORC2 signaling is reduced by long-term treatment with rapamycin [5, 6]. Based on its inhibition of these complexes, rapamycin is used as an anti-fungal agent, immune-suppressive agent and anti-tumor agent. Some new inhibitors of mTOR, such as Torin2 and NVP-BEZ235, have also been developed for the inhibition of mTORC1 and mTORC2 [7, 8]. Evidence using these inhibitors suggests that rapamycin affects platelet aggregation, dense granule secretion, spreading on fibrinogen and clot retraction, and thrombus formation [9-13]. However, because mTOR genedeletion mice die during early preimplantation [14], the role of mTOR in platelets has not been evaluated using gene knockout technology.

The mTORC1 and mTORC2 complexes have been shown to phosphorylate and activate a variety of downstream signaling mediators, including S6K1, S6, and Akt $[4,15,16]$. Additionally, mTOR interacts with mitogenactivated protein kinases, including Erk, in various cell types[17, 18] PKCs have been reported to be regulated by mTOR in various cell types [4] and to mediate platelet aggregation, dense- and alpha-granule secretion, and $\alpha_{\mathrm{IIb}} \beta_{3}$ activation and spreading on fibrinogen $[9,10,13$, $19-34]$. The expression of $\mathrm{cPKC} \alpha, \mathrm{cPKC} \beta, \mathrm{nPKC} \delta$ and $\mathrm{nPKC} \theta$ in human platelets has been well established [33, $35,36]$, though the expression of PKC $\eta$ in human platelets has been disputed [28, 33, 35-37]. Furthermore, $\mathrm{PKC \varepsilon}$ is expressed in human megakaryocytes, but not in human platelets $[28,36,38]$, while mouse platelets express PKCe $[28,39]$. The phosphorylation of Thr497 [27] in the activation loop of PKC $\alpha$, Thr505 [35] in the activation loop of PKC $\delta$, and Thr538 [40, 41] in the activation loop of $\mathrm{PKC} \theta$, is thought to be critical for their activity [42], and the phosphorylation of PKC $\beta$ Thr641, PKC $\beta$ Ser660 [27], and PKCe Ser729 [20], has been shown to be essential for activation [42].

In this study, we generated a mouse model with megakaryocyte/platelet-specific deletion of the mTOR gene. Our results demonstrate that mTOR plays positive roles in thrombus formation in vitro when perfused on lowconcentration collagen-coated surfaces and in vivo in response to low-extent $\mathrm{FeCl}_{3}$-induced injury. The regulation of thrombus formation in vitro was found to be dependent on the collagen concentration and dependent on the extent of $\mathrm{FeCl}_{3}$-induced injury in vivo. We also demonstrate that mTOR plays a positive role in lowdose GPVI-mediated platelet activation. These findings provide direct evidence for a pivotal role of mTOR in platelets.

\section{Materials and methods Reagents}

Thrombin, ADP, apyrase, PGE1, and rapamycin were from Sigma-Aldrich. Collagen and luciferase were from Chrono-Log Corp. Human fibrinogen was from Enzyme Research Laboratories (South Bend, IN, USA). APCconjugated fibrinogen, GYPGKF- $\mathrm{NH}_{2}$ (a Protease-activated receptor-4 (PAR4) agonist peptide) and synthetic collagen-related peptide (CRP) [43] were kindly donated by Peter J. Newman (Blood Center of Wisconsin; Milwaukee, WI, USA). PE-conjugated anti-mouse CD41 $\left(\alpha_{\text {II }} b\right)$, FITC-conjugated anti-mouse CD62 (P-selectin), and antibodies to $\mathrm{PKC}, \mathrm{PKC} \beta, \mathrm{PKC} \theta$, and $\mathrm{PKC} \varepsilon$ were from BD Biosciences. FITC-conjugated anti-mouse GPVI (JAQ1), FITC-conjugated anti-mouse CD42b (Xia. B2), and PE-labeled JON/A antibodies were from Emfret Analytics (Eibelstadt, Germany). Antibodies to mTOR, Rictor (D16H9), phospho-Akt Ser473, $\beta$-actin (SH10D10), S6K1, phospho-PKC Substrate Motif $[(\mathrm{R} / \mathrm{KXpSX}(\mathrm{R} / \mathrm{K})]$ (be usually thought to recognize substrates of cPKCs), and phospho-Lyn Tyr507 were from Cell Signaling Technology. Torin 1 and antibodies to phospho-PKC $\mathrm{Thr} 505$, S6, phospho-S6 Ser235/236, phospho-Erk Thr202/Tyr204, and Erk were kindly provided by Hanming Shen (professor at the National University of Singapore). Antibodies to Raptor, phospho-PKC $\alpha$ Thr497, PKC $\alpha$, and phosphoPKC $\beta$ Ser660, were obtained from Abcam. Antibodies to phospho-S6K1 Thr389, phospho-PKCe Ser729, and phospho-PKC $\beta$ Thr641, were from Santa Cruz Biotechnology. Antibodies to phospho-PKC $\theta$ Thr538 were kindly provided by Hanming Shen/purchased from Santa Cruz Biotechnology. Rottlerin was from Merck Biosciences (Beeston, United Kingdom). Go 6976 was from Biomol (Enzo Life Sciences). Calcein was from Invitrogen (Eugene, OR, USA). Fluorescein-labeled phalloidin was from Molecular Probes (Eugene, OR, USA). Other reagents were of analytical grade. The $\delta$ V1-1 (selective PKC $\delta$ peptide inhibitor, SFNSYELGSL) [21, 44], $\varepsilon V 1-2$ (selective $\mathrm{PKC} \varepsilon$ peptide inhibitor, EAV SLK PT) [45-48], were synthesized and purified ( $\geq 98 \%$ ) by China Peptides Co., Ltd. (Shanghai, China). The peptides were conjugated to the Tat-carrier peptide (YGR KKR RQR RR) [49] via a cysteine-cysteine $\mathrm{S}-\mathrm{S}$ bond at its $\mathrm{N}$ terminus.

\section{Mice}

$\mathrm{mTOR}^{\mathrm{fl} / \mathrm{fl}}$ mice [50] in a C57BL/6 genetic background were mated with PF4-Cre + mice [51] to obtain $\mathrm{mTOR}^{\mathrm{fl} /}$ ${ }^{\text {wt }} \mathrm{PF} 4-\mathrm{Cre}+$ mice. Further backcrossing with $\mathrm{mTOR}^{\mathrm{f} / \mathrm{fl}}$ gave rise to $\mathrm{mTOR}^{\mathrm{f} / / \mathrm{l}} \mathrm{PF} 4-\mathrm{Cre}+\left(\mathrm{mTOR}^{-/-}\right)$mice, which have mTOR deficiency in their platelets. PCR was used 
for genotyping the mice, while western blots were used for confirming the deletion of mTOR in platelets. Genotyping was performed by PCR, using the primer pair PF4-Cre F/PF4-Cre $\mathrm{R}$ (predicted 450 bp product in PF4Cre positive mice) and primer pair mTOR ${ }^{\mathrm{f} / \mathrm{fl}} \mathrm{F} / \mathrm{mTOR}^{\mathrm{fl} /}$ ${ }^{\mathrm{fl}} \mathrm{R}$ (expected product $349 \mathrm{bp}$ in WT; 349/533 bp in $\mathrm{mTOR}^{\mathrm{fl} / \mathrm{wt}}$; and $533 \mathrm{bp}$ in $\mathrm{mTOR}^{\mathrm{f} / \mathrm{fl}}$ ). The sequences of these primers are as follows: PF4-Cre Forward: $5^{\prime}-\mathrm{CCC}$ ATACAGCACACCTTTTG-3'; PF4-Cre Reverse: 5'-TGCACAGTCAGCAGGTT-3'; mTOR $^{\mathrm{fl} / \mathrm{fl}}$ Forward: $5^{\prime}$-TTATGTTTGATAATTGCA GTTTTGGCTAGC AGT-3'; mTOR ${ }^{\mathrm{fl} / \mathrm{fl}}$ Reverse: $5^{\prime}$-TTTAGGACTCCTTCT GTGACATAC ATTTCCT- $3^{\prime}$. All experiments were performed under the Guide for the Care and Use of Laboratory Animal (The National Academy Press, 2011) and were approved by the Board of Animal Study of Zhejiang University. $\mathrm{mTOR}^{\mathrm{fl} / \mathrm{fl}} \mathrm{PF} 4-\mathrm{Cre}^{+}\left(\mathrm{mTOR}^{-/-}\right)$and PF4-Cre ${ }^{-}$(Wild-type, WT) littermate mice at the age of 8-12 weeks were used for experiments.

\section{Assessment of hematologic parameters}

Hematologic parameters were determined on ethylenediamine tetraacetic acid samples collected from mice using an automatic cell counter (Sysmex F-820, Kobe, Japan).

\section{Platelet preparation}

Mice were anesthetized by intraperitoneal injection with chloral hydrate. Whole blood was collected from the inferior vena cava and anticoagulated with $1 / 8 \mathrm{vol}$ ACD ( $75 \mathrm{mM}$ sodium citrate, $39 \mathrm{mM}$ citric acid, and $135 \mathrm{mM}$ dextrose, $\mathrm{pH}$ 6.5). The blood was then diluted 1:1 with Modified Tyrode's buffer (20 mM HEPES, $137 \mathrm{mM} \mathrm{NaCl}$, $13.8 \mathrm{mM} \mathrm{NaHCO} 3,2.5 \mathrm{mM} \mathrm{KCl}, 0.36 \mathrm{mM} \mathrm{NaH} \mathrm{PO}_{4}$, $5.5 \mathrm{mM}$ glucose, $\mathrm{pH}$ 7.4) and centrifuged for $10 \mathrm{~min}$ at 180g; platelet-rich plasma (PRP) was collected in a fresh tube. Platelet pellets were obtained by centrifugation of the PRP at $700 \times g$ for $10 \mathrm{~min}$, washing in HEPES-buffered Tyrode containing $1 / 9$ vol ACD and $50 \mathrm{ng} / \mathrm{mL}$ PGE1 and resuspension in modified Tyrode's buffer $(20 \mathrm{mM}$ HEPES, $137 \mathrm{mM} \mathrm{NaCl}, 13.8 \mathrm{mM} \mathrm{NaHCO} 3,2.5 \mathrm{mM} \mathrm{KCl}$, $0.36 \mathrm{mM} \mathrm{NaH}_{2} \mathrm{PO}_{4}, 5.5 \mathrm{mM}$ glucose, $\mathrm{pH}$ 7.4) as previously described [52].

\section{Aggregation and dense granule secretion (ATP release)}

Platelet aggregation and dense granule secretion (ATP release) experiments were performed as described previously [53]. Briefly, washed platelets and PRP were challenged with the indicated agonists at $37{ }^{\circ} \mathrm{C}$ while they were stirred using an aggregometer (ChronoLog; Havertown, PA, USA), and dense granule secretion (ATP release) was measured by ATP release and monitored in parallel with aggregation by the addition of luciferin/ luciferase. Washed platelets $\left(2.0 \times 10^{8} / \mathrm{mL}\right)$ in modified
Tyrode's buffer were challenged with GYPGKF-NH $\mathrm{N}_{2}$, collagen, and CRP, while PRP was stimulated with ADP. The platelets were incubated with the indicated inhibitors at a temperature of $37^{\circ} \mathrm{C}$ for $10 \mathrm{~min}$ before stimulation.

\section{Flow cytometry}

Flow cytometric analysis was performed and developed as described previously [54]. Washed platelets were diluted to $2.0 \times 10^{7} / \mathrm{mL}$ in modified Tyrode's buffer with $\mathrm{Ca}^{2+}$ and were pre-incubated with either FITC-conjugated CD62P, FITC-conjugated GPVI, PE-conjugated CD41, PE-conjugated JON/A, APC-conjugated fibrinogen, FITC-conjugated CD42b, or isotype control antibodies. In some experiments, agonists were used to stimulate the washed platelets after incubation with antibodies as indicated [54]. The samples were fixed by adding $2 \%$ (vol/ vol) formaldehyde. Flow cytometry was performed using a FACS Calibur flow cytometer.

\section{Western blotting}

Washed platelets were resuspended and adjusted to $2 \times 10^{8} / \mathrm{mL}$ in Tyrode's buffer. Then, the platelets were stimulated with the indicated agonists in a Chrono-Log Aggregometer at $37{ }^{\circ} \mathrm{C}$ for $5.5 \mathrm{~min}$. Immunoblotting was carried out as described previously[55]. Lysates were prepared and analyzed by SDS-PAGE, electrotransferred to PVDF membranes, blocked with 5\% (w/v) BSA in TBST and probed with primary antibodies. The membranes were washed in TBST and incubated with appropriate secondary antibodies. Immunoreactive bands were visualized with enhanced chemiluminescence detection reagents using a Syngene G: BOX Chemi XR system and quantified by Image J.

\section{In vitro thrombus formation under flow conditions}

Thrombus formation was assessed and developed as described previously [56] using a BiofluxTM 200 system (Fluxion, South San Francisco, CA). Briefly, Bioflux plates were primed and coated overnight with $20 \mu \mathrm{g} / \mathrm{mL}$ or $50 \mu \mathrm{g} / \mathrm{mL}$ of fibrillar collagen I and then blocked with $0.5 \% \mathrm{BSA} / \mathrm{PBS}(\mathrm{W} / \mathrm{V})$ solution for $15 \mathrm{~min}$. Whole blood was labeled with mepacrine at $37^{\circ} \mathrm{C}$ for $30 \mathrm{~min}$ and then perfused in micro-channels at a shear force of 40 dynes/ $\mathrm{cm}^{2}$ for $5 \mathrm{~min}$, during which time platelet adhesion and aggregation were monitored by fluorescent microscopy. After perfusion, the adherent platelets were observed with an inverted fluorescence microscope (Nikon Ti-S, Tokyo, Japan). The coverage area of the platelets and the fluorescence intensity were measured using Bioflux software (Fluxion). 


\section{Statistical analysis}

The results are expressed as means \pm SEM. The paired or unpaired Student $t$-test was used to evaluate the statistical significance of the data.

\section{Results}

Megakaryocyte- and platelet-specific mTOR-deficient mice display normal hematopoietic parameters but their platelets show impaired thrombus formation when perfused on low-concentration collagen-coated surfaces

mTOR gene knockout embryos of mice are severely runted and die during early preimplantation [14]. Therefore, we used Cre recombinase-mediated excision to delete mTOR specifically in megakaryocytes and platelets. To confirm platelet-specific gene deletion, we used polymerase chain reaction to genotype $\mathrm{mTOR}^{\mathrm{fl} /}$ $\mathrm{fl}, \mathrm{mTOR}^{\mathrm{fl} / \mathrm{wt}} \mathrm{PF} 4-\mathrm{Cre}+\left(\mathrm{mTOR}^{+/-}\right)$and $\mathrm{mTOR}^{\mathrm{fl} / \mathrm{fl}} \mathrm{PF}^{-}$ $\mathrm{Cre}+\left(\mathrm{mTOR}^{-1-}\right)$ mice (Fig. 1a). Western blotting confirmed mTOR specifically-deficient in platelets (Fig. 1b). The surface expression of platelet glycoproteins CD41 $\left(\alpha_{\mathrm{IIb}} \beta_{3}\right), \mathrm{CD} 42 \mathrm{~b}(\mathrm{GPIb} \alpha)$ and GPVI was similar in the knockout mice and PF4-Cre ${ }^{-}$(Wild-type, WT) littermate controls (Fig. 1c). Furthermore, $\mathrm{mTOR}^{-1-}$ mice survived at about $100 \%$ of the expected Mendelian frequency (Additional file 1: Table S1). These results verify the successful deletion of mTOR in $\mathrm{mTOR}^{-1-}$ mice platelets and also suggest that survival was not significantly affected by megakaryocyte- and platelet-specific mTOR deletion.

To determine whether megakaryocyte- and plateletspecific mTOR deletion affects the distribution of cells, including platelets, in peripheral blood, blood from littermate WT and $\mathrm{mTOR}^{-1-}$ mice was collected. As shown in Table 1, the platelet counts (PLTs), mean platelet volume (MPV), platelet distribution width (PDW), red blood cell count (RBCs), hemoglobin (HGB) and white blood cell count (WBCs) were normal in $\mathrm{mTOR}^{-1-}$ mice $(\mathrm{P}>0.05$; $\mathrm{n}=12)$.

To examine the activity of $\mathrm{mTOR}^{-1-}$ platelets under flow conditions, we used a whole-blood microfluidic perfusion system. Platelets from mice blood were pre-incubated and labeled using mepacrine and then perfused on $20 \mu \mathrm{g} / \mathrm{mL}$ or $50 \mu \mathrm{g} / \mathrm{mL}$ type I fibrillar collagen-coated surfaces. The accumulated platelet adhesion area and fluorescence intensity were quantified and as a measure of thrombus formation. For $20 \mu \mathrm{g} / \mathrm{mL}$ type I fibrillar collagen-coated surfaces, smaller thrombi were formed after perfusion with blood from $\mathrm{mTOR}^{-1-}$ mice than that from WT mice (Fig. 1d-f). However, for higher concentration $(50 \mu \mathrm{g} / \mathrm{mL})$ collagen-coated surfaces, the defective thrombus formation in $\mathrm{mTOR}^{-1-}$ blood was overcame (Fig. 1g-i).
These results suggest that, although the platelets in $\mathrm{mTOR}^{-/-}$mice were produced at normal levels, they have the impaired ability to form thrombi on low-concentration collagen-coated surfaces, which was recovered on higher-concentration collagen-coated surfaces. To verify these results, we perfused reconstituted blood containing the same concentration of calcein-labeled platelets $\left(2.0 \times 10^{8} / \mathrm{mL}\right)$ onto $20 \mu \mathrm{g} / \mathrm{mL}$ or $50 \mu \mathrm{g} / \mathrm{mL}$ type I fibrillar collagen-coated surfaces. Similar results were obtained as that in the whole blood experiments (Additional file 1: Figure S1).

$\mathrm{FeCl}_{3}$-induced mesenteric arteriole thrombosis models were used to investigate in vivo thrombus formation. The ratio of occluded mice showed a significant difference ( $4 / 8$ for WT vs $2 / 7$ for mTOR ${ }^{-1-}$ ) for mice with a lower extent of injury, especially within the first $40 \mathrm{~min}$ (3/8 for WT vs $0 / 7$ for $\mathrm{mTOR}^{-1-}$ ). Moreover, the occlusion time of the injured mesentery arteriole was proportionally longer for $\mathrm{mTOR}^{-/-}$mice compared to WT mice with a minor injury. Additionally, there was no significant difference between $\mathrm{mTOR}^{-1-}$ mice and WT mice with a higher extent of injury.

In addition, WT and $\mathrm{mTOR}^{-1-}$ mice showed dosedependent responses to the injury. The difference in $\mathrm{mTOR}^{-1-}$ mice was far greater than that in WT mice in response to the different extent of injury. The dose effect on the extent of injury in WT mice was observed as follows: the ratio of occluded mice ( $4 / 8$ for lower extent injury vs $8 / 12$ for higher extent injury, and $3 / 8$ vs $8 / 12$ within the first $40 \mathrm{~min}$ ) and the occlusion time of the mesentery arteriole response to the varying extent of injury were different $(\mathrm{P}<0.05)$. For the $\mathrm{mTOR}^{-/-}$ mice: the ratio of occluded mice $(2 / 7$ for lower extent injury vs $9 / 11$ for higher extent injury, and $0 / 7$ vs $9 / 11$ within the first $40 \mathrm{~min}$ ) and the occlusion time of the mesentery arteriole after being subjected to varying levels of injury were remarkably different $(\mathrm{P}<0.01)$ (Additional file 1: Figure S2). These results suggest that in vivo thrombus formation was proportional to the extent of injury in WT and $\mathrm{mTOR}^{-1-}$ mice, and the dose-dependent effect was far greater in $\mathrm{mTOR}^{-1-}$ mice than in WT mice in regard to the results of the ratio of occluded mice and the occlusion time of the mesentery arteriole.

Collectively, these results suggest that mTOR positively regulates thrombus formation, both in vitro and in vivo, when perfused on low-concentration collagen-coated surfaces or after being subjected to less severe $\mathrm{FeCl}_{3}$-induced injury, respectively. Moreover, mTOR performs these functions in a dose-dependent manner. 
Fig. 1 Deletion of mTOR protein in platelets. a Genotyping of $\mathrm{mTOR}^{\mathrm{fl} /}$ ${ }^{f}$, $\mathrm{mTOR}^{\mathrm{f} / \mathrm{wt}} \mathrm{PF} 4-\mathrm{Cre}+\left(\mathrm{mTOR}^{+/-}\right)$and $\mathrm{mTOR}^{\mathrm{fl} / \mathrm{f}} \mathrm{PF} 4-\mathrm{Cre}+\left(\mathrm{mTOR}^{-/-}\right)$ mice using polymerase chain reaction. The top and bottom images were cropped from different gels and full-length/original gels were shown in Additional file 3: Part III. b Lysates from PF4-Cre ${ }^{-}$ (wildtype, WT, W) littermate, or mTOR ${ }^{-1-}(\mathrm{KO}, \mathrm{K})$ platelets were immunoblotted with mTOR, Raptor, Rictor, and Actin antibodies, these images (separated by horizontal white space) were cropped from the different/same gels and full-length/original blots were shown in Additional file 3: Part III. c Flow cytometric analysis of the surface expression of CD41 ( $a_{\| b} \beta_{3)}, C D 42 b$ (GPIba), and GPVI of resting WT and $\mathrm{mTOR}^{-1-}$ murine platelets. Results are expressed as mean fluoresce intensity (MFI) \pm SEM $(n=3)$. $\mathbf{d}$-f Representative photomicrographs and quantification of the adhesion and aggregation of WT or $\mathrm{mTOR}^{-/-}$platelets on $20 \mu \mathrm{g} / \mathrm{mL}$ or $\mathbf{g - i} 50 \mu \mathrm{g} /$ $\mathrm{mL}$ type I fibrillar collagen-coated surface. The fluorescent platelets adhering to coated Bioflux micro flow chambers were recorded by video (exposure time were fixed as 1.5 or $0.8 \mathrm{~s}$, respectively). The coverage surface area and total integrated fluorescence were quantified by Bioflux software (Fluxion) as a measure of platelet thrombi formation. Quantified results are expressed as the mean percentage of surface coverage (left panels) or mean integrated fluorescence intensity (right panels) \pm SEM ( $n \geq 3$ per group, * indicates $P<0.05$, paired Student's $t$ test)

$\mathrm{mTOR}^{-l-}$ platelets exhibit impaired aggregation and dense granule secretion (ATP release) after stimulation with low doses of the GPVI agonist CRP or the PAR4 agonist GYPGKF-NH

To further evaluate the effects of mTOR deletion on platelet activity, we assessed the aggregation and dense granule secretion (ATP release) of platelets after activation with low and high doses of: GPVI agonist CRP (collagen-related peptide) $(0.75 \mu \mathrm{g} / \mathrm{mL}$ and $4 \mu \mathrm{g} / \mathrm{mL})$; PAR4 (protease-activated receptor-4) agonist GYPGKF-NH $\mathrm{NH}_{2}$ (0.75 $\mathrm{mM}$ and $3.2 \mathrm{mM})$; and ADP $(4 \mu \mathrm{M}$ and $30 \mu \mathrm{M})$ (Fig. 2a-c). After activation with a low dose of CRP, $\mathrm{mTOR}^{-/-}$platelets displayed impaired activity in aggregation (Fig. 2a, d) and dense granule secretion (ATP release) (Fig. 2a, g); however, these deficiencies were overcame by high-dose activation (Fig. 2a, d, h). This pattern was also replicated for GYPGKF- $\mathrm{NH}_{2}$, though the effect of mTOR deficiency was less obvious (Fig. 2b, e, i, j). In contrast, the aggregation level of $\mathrm{mTOR}^{-/-}$platelets that were induced by $\operatorname{ADP}(4 \mu \mathrm{M}$ and $30 \mu \mathrm{M})$ was similar to that of WT platelets (Fig. 2c, f). These results suggest that $\mathrm{mTOR}^{-/-}$platelets are specifically impaired in their response to activation by GPVI and PAR4 at low concentrations.

mTOR $^{-1-}$ platelets show impaired activation of $a_{1 \mathrm{lb}} \beta_{3}$, but normal a-granule secretion after induction with GPVI/ PARs agonists at low concentrations

To further characterize the deficiency in $\mathrm{mTOR}^{-/-}$ platelets, we used the $\alpha_{\text {IIb }} \beta_{3}$-specific antibody JON/A

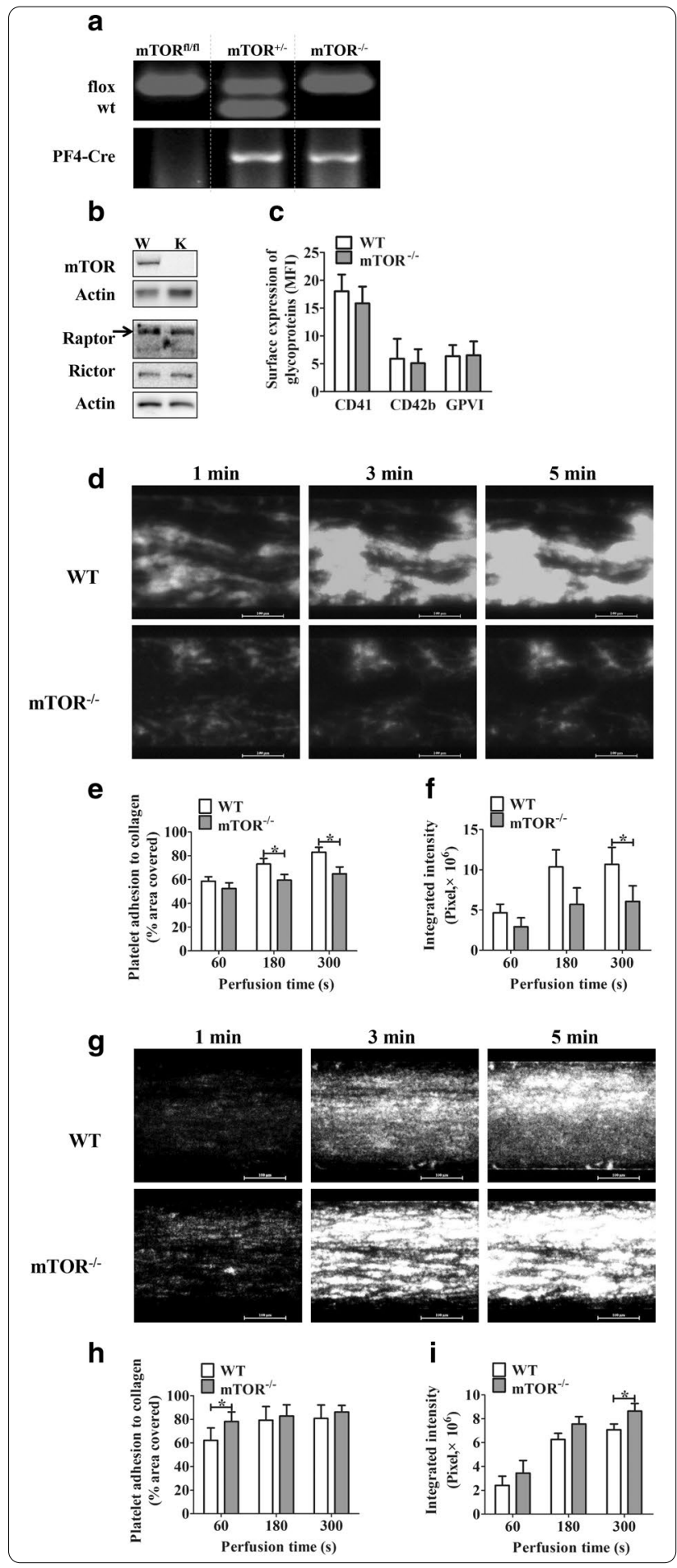

or APC-fibrinogen to assess the activation of integrin $\alpha_{\mathrm{IIb}} \beta_{3}$ upon stimulation with increasing doses of the PAR agonist thrombin and the GPVI agonist collagen. $\mathrm{mTOR}^{-/-}$platelets showed impaired activation of $\alpha_{\text {IIb }} \beta_{3}$ after stimulation with a low doses of thrombin or 
Table 1 Hematologic parameters in wild-type (WT) and $\mathrm{mTOR}^{-/-}$mice

\begin{tabular}{lccc}
\hline $\begin{array}{l}\text { Hematologic } \\
\text { parameter }\end{array}$ & WT $(\mathbf{n}=\mathbf{1 2})$ & $\mathbf{m T O R}^{-1-}(\mathbf{n}=\mathbf{1 2})$ & P-value \\
\hline PLTs $(\mathrm{K} / \mu \mathrm{L})$ & $856.67 \pm 46.78$ & $922.50 \pm 33.60$ & 0.265 \\
$\mathrm{MPV}, \mathrm{fl}$ & $5.16 \pm 0.058$ & $5.23 \pm 0.04$ & 0.360 \\
$\mathrm{PDW}, \mathrm{fl}$ & $5.97 \pm 0.08$ & $6.10 \pm 0.08$ & 0.219 \\
$\mathrm{RBCs}(\mathrm{M} / \mu \mathrm{L})$ & $10.34 \pm 0.34$ & $10.26 \pm 0.25$ & 0.844 \\
$\mathrm{HGB}(\mathrm{g} / \mathrm{dL})$ & $14.67 \pm 0.54$ & $14.42 \pm 0.42$ & 0.718 \\
WBCs $(\mathrm{K} / \mu \mathrm{L})$ & $6.03 \pm 0.65$ & $5.04 \pm 0.53$ & 0.254 \\
\hline
\end{tabular}

Whole blood from WT or $\mathrm{mTOR}^{-1-}$ mice was collected and used for analyzing the hematologic parameters

PLTs platelets, MPV mean platelet volume, $P D W$ platelet distribution width, $R B C s$ red blood cells, $H G B$ hemoglobin, $W B C s$ white blood cells

The data are presented as means \pm SEM $(P>0.05$ is nonsignificant for all hematologic parameters)

collagen; however, the levels of activation of $\alpha_{\mathrm{IIb}} \beta_{3}$ were not affected by mTOR deficiency, when stimulated at higher concentrations $(0.1$ and $1 \mathrm{U} / \mathrm{mL}$ thrombin; 1.5 or $10 \mu \mathrm{g} / \mathrm{mL}$ collagen) (Fig. 3). However, the expression of P-selectin was not influenced by mTOR deficiency (Additional file 1: Figure S3), suggesting that the effect of mTOR deficiency may be specific for integrin $\alpha_{\mathrm{II}} \beta_{3}$.

The spreading of $\mathrm{mTOR}^{-/-}$platelets on $50 \mu \mathrm{g} / \mathrm{mL}$ [Additional file 1: Figure S4, as well as $10 \mu \mathrm{g} / \mathrm{mL}$ (data not shown)] fibrinogen were enhanced than WT platelets. However, the clot retraction was delayed in $\mathrm{mTOR}^{-/-}$ platelets compared with the WT platelets (Additional file 1: Figure S5). Taken together, these results suggested that mTOR may play different roles in early and late $\alpha_{\mathrm{II}} \beta_{3}$-mediated outside-in signaling (see Additional file 1: Results and Discussion).

\section{Identification of mTOR-dependent signaling molecules that are modulated in response to low-dose CRP}

To provide a molecular basis for reduced GPVI-mediated $\mathrm{mTOR}^{-/-}$platelet activation, we firstly investigated the phosphorylation of S6K1, S6, and Akt Ser473, each of which has been reported to be regulated by mTORC1 and mTORC2 $[4,15,16]$. The phosphorylation of S6K1 Thr389, S6 Ser235/236 (Fig. 4a-d), and Akt Ser473 (Fig. 4e-f) was significantly decreased in mTOR-deficient platelets in response to low-dose CRP $(0.75 \mu \mathrm{g} / \mathrm{mL})$, which verifies the impaired downstream signaling in $\mathrm{mTOR}^{-1-}$ platelets after GPVI stimulation. Our study shows that the phosphorylation of the S6 and Akt Ser473 in $\mathrm{mTOR}^{-1-}$ platelets was decreased to approximately $30 \%$ of that of WT platelets in GPVI signaling. Moreover, the phosphorylation of S6 and Akt Ser473 was ablated in some samples of $\mathrm{mTOR}^{-/-}$platelets after GPVI stimulation.

Furthermore, apyrase $(1 \mathrm{U} / \mathrm{mL})$ decreased the phosphorylation of S6 and Akt Ser473 in $\mathrm{mTOR}^{-/-}$platelets after induction with low-concentration collagen $(0.8 \mu \mathrm{g} /$ $\mathrm{mL}$ ). The phosphorylation level of S6/Akt Ser473 in $\mathrm{mTOR}^{-/-}$platelets decreased to a level similar to that of resting $\mathrm{mTOR}^{-1-}$ platelets when pre-incubated with apyrase. These findings occurred independently of whether there was substantive S6/Akt Ser473 phosphorylation in $\mathrm{mTOR}^{-1-}$ platelets when pre-incubated without apyrase. Conversely, apyrase played a less dramatic role on the phosphorylation of S6 in WT platelets than in mTOR ${ }^{-1-}$ platelets (for unknown reasons), although apyrase decreased the phosphorylation level of Akt Ser473 in WT platelets. The phosphorylation level of S6/Akt Ser473 in apyrase + collagen WT platelets was higher than that in resting WT platelets (Additional file 1: Figure S6). A similar decrease in the phosphorylation of S6 Ser235/236 and Akt Ser473 was also observed in mTOR-deficient platelets in response to low-dose PAR4-agonist GYPGKF$\mathrm{NH}_{2}(0.75 \mathrm{mM})$ (data not shown). These results confirm mTOR deficiency impaired the downstream signaling in platelets after GPVI stimulation.

We also examined effects on the phosphorylation of Lyn, which is activated by GPVI-mediated signals [57]. Lyn phosphorylation was similar in $\mathrm{mTOR}^{-1-}$ and WT platelets after induction with low-dose CRP (data not shown) which verifies the specificity of the GPVI-mediated mTOR-dependent signal.

mTOR also interacts with mitogen-activated protein kinases, including Erk, in various cell types [17, 18]. Consistently, the phosphorylation of Erk Thr202/Tyr204 was significantly decreased in mTOR-deficient platelets in response to low-dose CRP or PAR4 agonist (data not shown). Moreover, a similar decrease in the phosphorylation of these downstream signaling molecules in

(See figure on next page.)

Fig. $2 \mathrm{mTOR}^{-/-}$platelets exhibit impaired aggregation and dense granule secretion (ATP release) after stimulation of GPVI with low-dose CRP or stimulation with the PAR agonist GYPGKF-NH 2 . a Washed platelets from mTOR ${ }^{-/}$mice and WT littermates were challenged with $\mathrm{CRP}(0.75 \mu \mathrm{gg} / \mathrm{mL}$ or $4 \mu \mathrm{g} / \mathrm{mL})$ or $\mathbf{b}$ the PAR4 agonist GYPGKF-NH $2(0.75 \mathrm{mM}$ or $3.2 \mathrm{mM})$, and their aggregation and simultaneous ATP release were measured; $\mathbf{c}$ PRP was stimulated with ADP $(4 \mu \mathrm{M}$ or $30 \mu \mathrm{M})$ and platelet aggregation were measured; $\mathbf{d}-\mathbf{j}$ The calculated percentages of aggregation and ATP release. Results are presented as means \pm SEM from at least three experiments $\left({ }^{*} \mathrm{P}<0.05,{ }^{*} \mathrm{P}<0.01\right.$, paired Student's $t$ test). The arrows show "aggregation" or "ATP Release," indicating 90\% light transmission or 70\% ATP release, respectively 

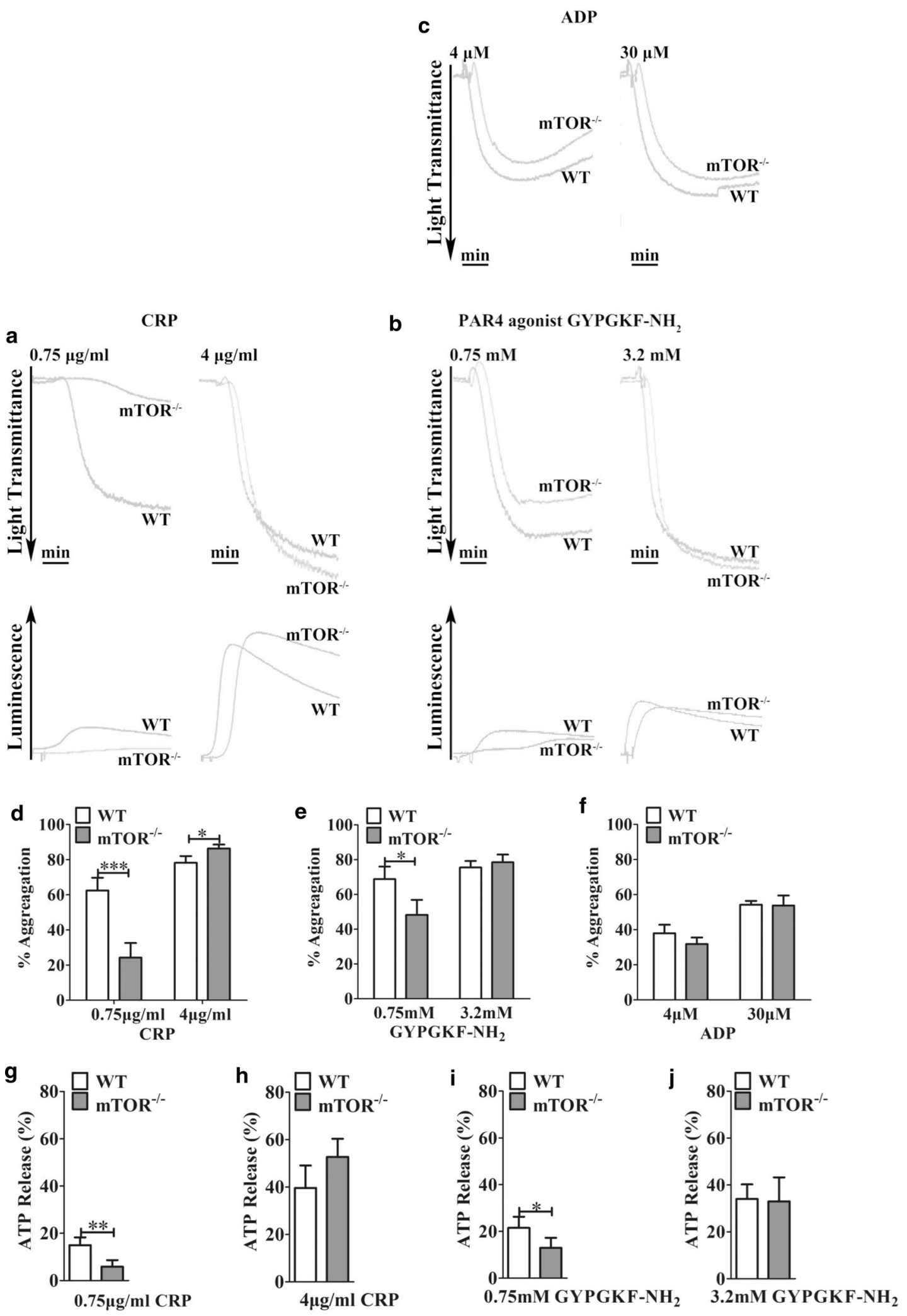


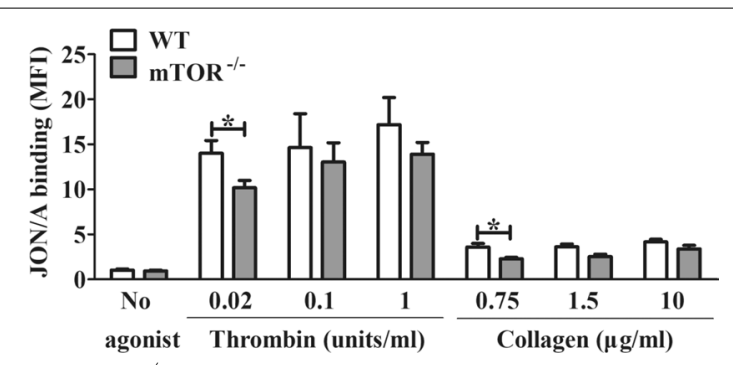

Fig. $3 \mathrm{mTOR}^{-/-}$platelets exhibit impaired activation of $\mathrm{a}_{\| \mathrm{b}} \beta_{3}$ after induction with low concentrations of collagen/CRP or the PAR agonist thrombin. Washed platelets were pre-incubated with phycoerythrin-labeled rat anti-mouse integrin $a_{\| b} \beta_{3} m A b$ (JON/A). Then, they were activated with thrombin, collagen/CRP. The mean fluorescence intensity (MFI) was measured by flow cytometry. Results are expressed as MFI \pm SEM $(n \geq 3)$. The data were analyzed for statistical significance using the Student's $t$ test $\left({ }^{*} P<0.05\right.$, ${ }^{*} P<0.01$ )

response to low-dose collagen $(0.8 \mu \mathrm{g} / \mathrm{mL})$ was observed in WT platelets after treatment with the mTOR inhibitor Torin1, although almost no change was observed for $\mathrm{mTOR}^{-1-}$ platelets after the same treatment (Additional file 1: Figure S7). These results verify the impaired downstream signaling molecules in $\mathrm{mTOR}^{-1-}$ platelets after low-dose GPVI stimulation.

PKCs also have been reported to be regulated by mTOR or mTORC2 in other cell types [4] and to mediate platelet aggregation, dense- and alpha- granule secretion, $\alpha_{\text {IIb }} \beta_{3}$ activation, and spreading on fibrinogen $[9,10,13,19-34]$. Furthermore, the expression of cPKC $\alpha, \mathrm{cPKC} \beta, \mathrm{nPKC} \delta$ and $\mathrm{nPKC} \theta$ have been observed in human platelets in many studies [9, 10, 13, 19-34]. The phosphorylation of Thr497 [27] in the activation loop of PKC $\alpha$, Thr505 [35] in the activation loop of PKC $\delta$, and Thr538 [40, 41] in the activation loop of $\mathrm{PKC} \theta$, is thought to be critical for kinase activity [42]. cPKC and nPKC must be phosphorylated at both their turn motif and hydrophobic motif to achieve catalytic competence. The phosphorylation of PKC $\beta$ Thr641, PKC $\beta$ Ser660 [27], and PKCe Ser729 [20] is also essential for activation [42]. Thus, to comprehensively examine the role of PKCs in platelet activation by low-dose CRP, we assessed the phosphorylation of an array of PKCs in WT and mTOR-deficient platelets. The phosphorylation of PKC $\alpha$ Thr497 (Fig. 5a, b), PKC $\beta$ Thr641 and Ser660 (Fig. 5c, e) and PKC $\theta$ Thr538 (Fig. 5f, g) were unaffected in low-dose CRP-activated $\mathrm{mTOR}^{-1-}$ platelets. Moreover, the cPKC activity, which was detected by a phosphorylated cPKC substrate antibody, showed little change in mTOR-deficient platelets when induced by a low concentration of collagen (data not shown).

However, the phosphorylation of PKC $\delta$ Thr505 (Fig. 5h, i) and PKCE Ser729 (Fig. 5j, k) was enhanced by low-dose CRP in mTOR-deficient platelets. Torin1 increased the phosphorylation of PKC $\delta$ Thr505 and PKC $\varepsilon$ Ser729 in WT platelets after low-dose collagen stimulation with GPVI (Additional file 1: Figure S7). Moreover, the increased phosphorylation of PKC $\delta$ Thr505 and PKCE Ser729 in mTOR $^{-1-}$ platelets after stimulation with low-dose collagen was restored by the addition of Torin 1, which also supports the possibility that PKC $\delta$ and $\mathrm{PKC} \varepsilon$ are regulated by mTOR (Additional file 1: Figure S7). Furthermore, ADP restored the decreased phosphorylation of S6 Ser235/236, Akt Ser473, as well as increased phosphorylation of PKC $\delta$ Thr505 and PKCe Ser729 in mTOR $^{-1-}$ platelets when stimulated with GPVI agonist collagen at a low dose (Additional file 1: Figure S7).

To further examine the potential role of PKCs on mTOR-regulated platelet activation, we assessed the effects of treating platelets with the PKC $\delta$ inhibitor rottlerin and the PKC $\alpha / \mathrm{PKC} \beta 1$ inhibitor Go 6976. Rottlerin potentiated the aggregation of WT platelets and restored the full aggregation and dense granule secretion (ATP release) of $\mathrm{mTOR}^{-/-}$platelets in response to low-dose collagen $(0.5 \mu \mathrm{g} / \mathrm{mL})$ (Fig. $6 \mathrm{a}-\mathrm{c})$, while Go 6976 did not restore them (Fig. 6d-f). However, Go 6976 exhibited a trend of decrease aggregation and dense granule secretion (ATP release) (Fig. 6d-f).

PKC isoform-specific peptide inhibitors, such as $\delta \mathrm{V} 1-1, \varepsilon \mathrm{V} 1-2, \theta \mathrm{V} 1-1, \alpha \mathrm{C} 2-4, \beta \mathrm{C} 2-1$, and $\beta \mathrm{C} 2-4$, are reported to inhibit the interaction of PKCs with their specific RACK adaptor proteins, which essentially block them from translocating to their specific target substrates [21, 41, 44-48, 58-60]. Moreover, peptides $\delta$ V1-1 [21] and $\theta$ V1-1 [41] were used in studying the role of PKC isoforms in platelets. The use of peptide $\varepsilon V 1-2$ [20] also has been mentioned in a study of platelets, although the data were not shown. The PKC $\delta$ peptide inhibitor $\delta \mathrm{V} 1-1$ rescued the aggregation of $\mathrm{mTOR}^{-/-}$platelets in response to low-dose collagen, whereas the $\mathrm{PKC} \varepsilon$ peptide inhibitor had a similar but minimal role in rescuing the aggregation of $\mathrm{mTOR}^{-/-}$ platelets in response to low-dose collagen (Additional file 1: Figure S8).

These results suggest that $\mathrm{PKC} \delta / \varepsilon$, especially $\mathrm{PKC} \delta$, may be involved in low-dose GPVI agonist-induced mTOR-dependent signaling but $\mathrm{PKC} \alpha / \beta$ and $\mathrm{PKC} \theta$ are not involved. 
a

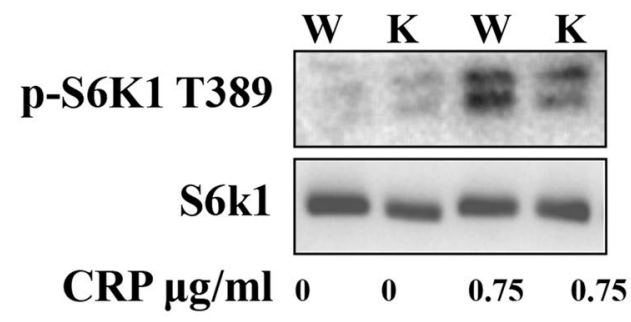

C

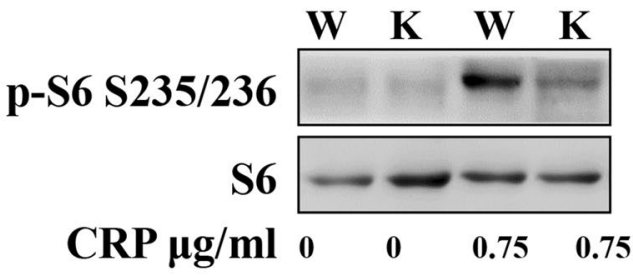

e

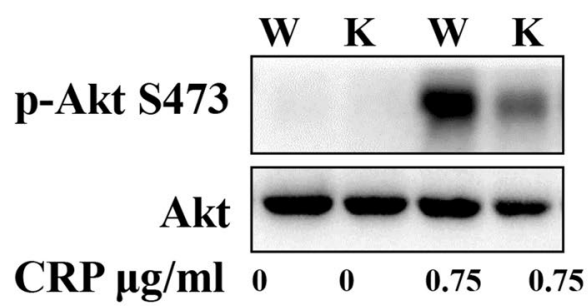

b

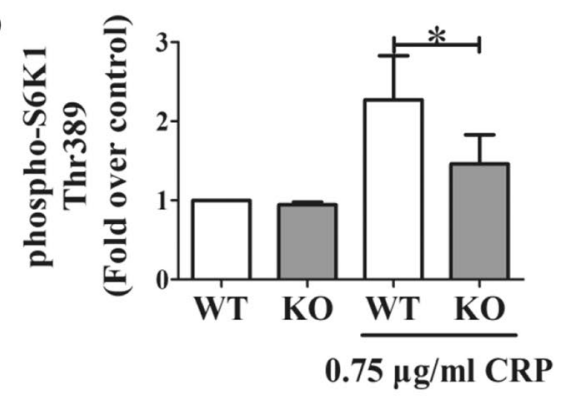

d

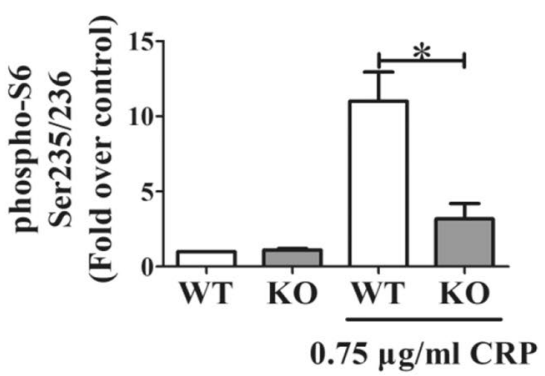

f

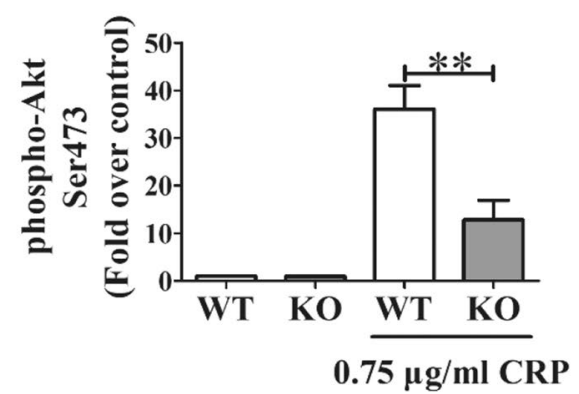

Fig. 4 mTOR deficiency impairs low-dose CRP induced phosphorylation of S6K1, S6, and Akt Ser473. Platelets from WT (W) or mTOR ${ }^{-1-}$ (KO, K) mice were stimulated with CRP at the indicated low concentration under aggregating conditions for $5.5 \mathrm{~min}$. Lysates of platelets were immunoblotted with antibodies to a, b phospho-S6K1 Thr389 and S6K1, c, d phospho-S6 Ser235/236 and S6, or e, f phospho-Akt Ser473 and Akt; these images (separated by horizontal white space) were cropped from the different/same gels and full-length/original blots were shown in Additional file 3: Part III. Phosphoprotein levels were normalized to S6K1 levels for panel b, to S6 levels for panel c, and to Akt levels for panels e. Relative values were standardized to 1 in unstimulated WT samples and represent means \pm SEM from at least three independent experiments $\left({ }^{*} P<0.05,{ }^{* *} P<0.01\right.$; paired Student's $t$ test $)$

\section{Discussion}

Whether the inhibitor of mTORC1-Sirolimus (rapamycin) enhances or impairs thrombus formation is a subject of debate [13, 61, 62]. Many studies using rapamycin suggest that mTOR plays a positive role in thrombopoiesis at different stages of thrombocytopoiesis in vivo or in vitro [61-64]. However, rapamycin has also been reported as an option for the therapy of idiopathic thrombocytopenic purpura in clinical trials [13]. Since genetic deletion of mTOR in mice affects the animal's survival [14], it is difficult to resolve these discrepancies using standard knockout methods. Therefore, we established megakaryocyte/platelet-specific mTOR deletion mice. Our results confirm the role of mTOR in low-dose-induced platelet aggregation and in in vitro thrombus formation (Additional file 1: Figure S9, as well as see Additional file 2).

Whole-blood/reconstituted-blood from $\mathrm{mTOR}^{-1-}$ mice displayed deficiencies in thrombus formation when perfused in lower concentration $(20 \mu \mathrm{g} / \mathrm{mL})$ collagen-coated flow chambers. These deficiencies in $\mathrm{mTOR}^{-1-}$ bloods were overcame when perfused in higher concentration $(50 \mu \mathrm{g} / \mathrm{mL})$ collagen-coated flow chambers.

These results demonstrate that mTOR functions as a positive regulator of thrombus formation when perfused in vitro on low-concentration collagen-coated surfaces, and that mTOR plays this role in a collagen dose-dependent manner. 


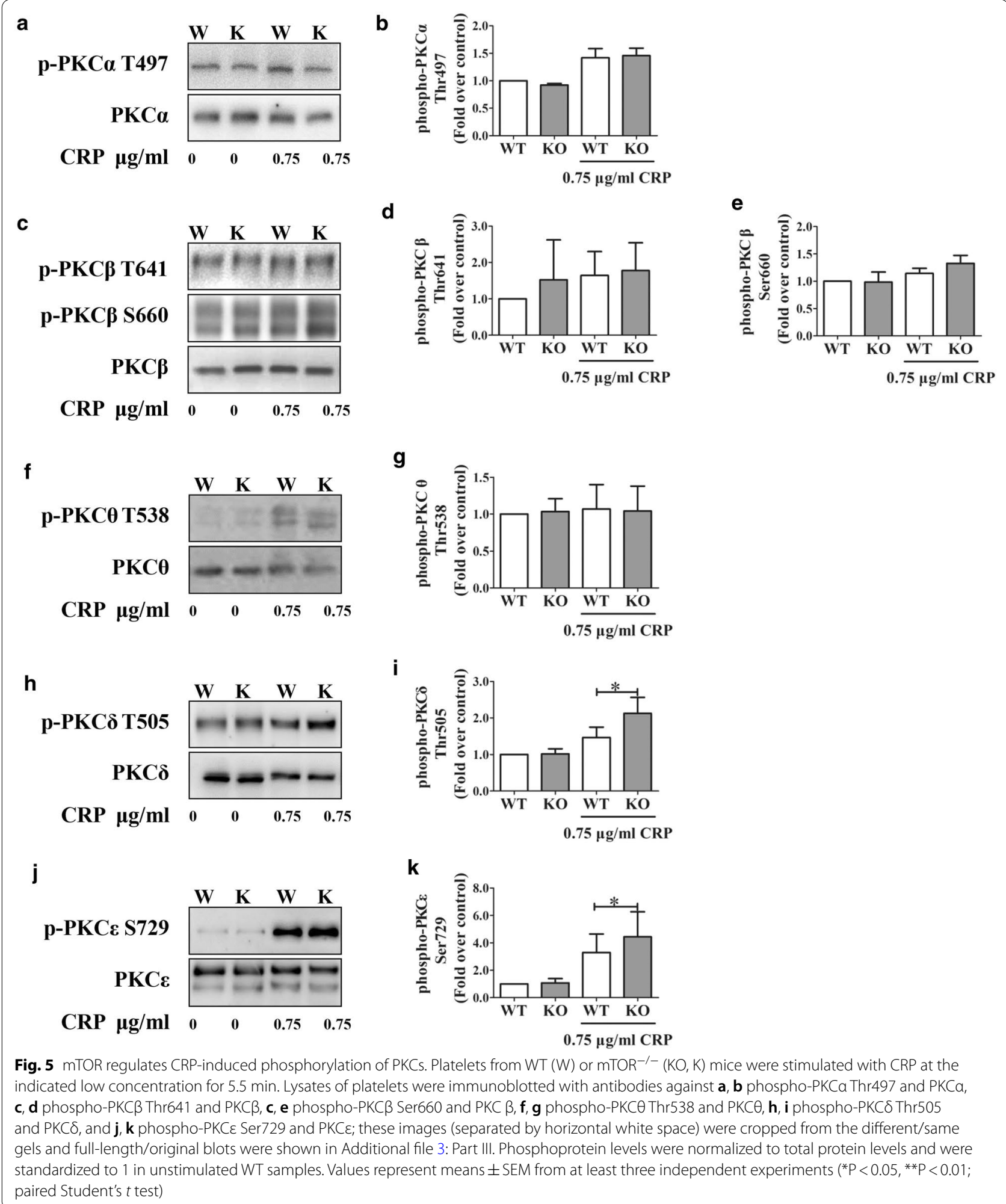

Similar to the results found in thrombus formation in vitro, mTOR positively regulates thrombogenesis in vivo after being subjected to less severe $\mathrm{FeCl}_{3}$-induced injury, and mTOR performs this function in a dosedependent manner, which is dependent on the extent of $\mathrm{FeCl}_{3}$-induced injury. Platelet-specific deletion of 


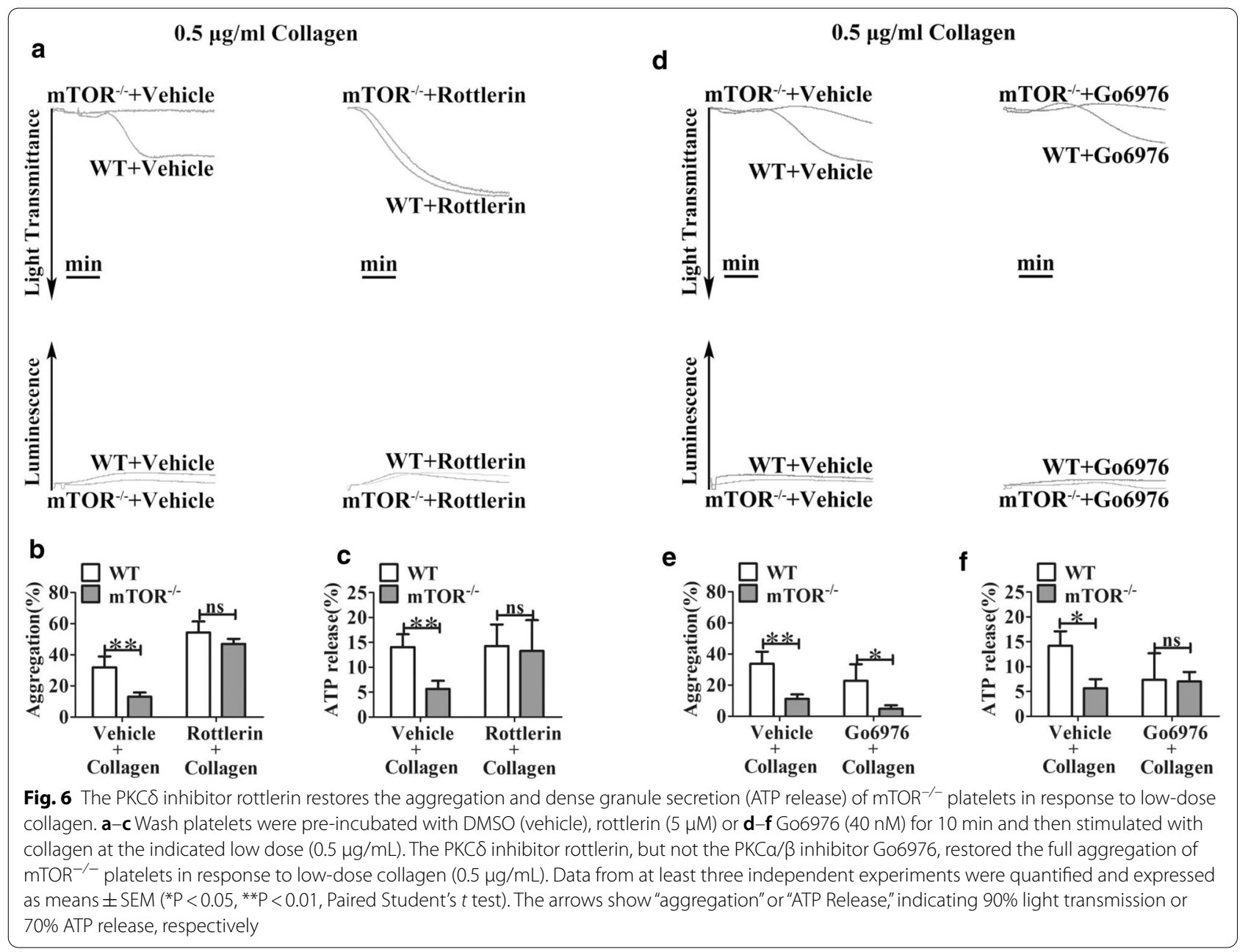

the Raptor gene, a component of mTORC1, has also been shown to impair thrombus formation in vivo [65]. The deletion of mTOR would be assumed to affect both mTORC1 and mTORC2 signaling. Nonetheless, our results could be explained by effects on one or both complexes. Our results also showed that in vivo thrombus formation in WT and $\mathrm{mTOR}^{-/-}$mice were proportional to the extent of injury, and the dose-dependent effect was far greater in $\mathrm{mTOR}^{-1-}$ mice than in WT mice. This dose-dependent effect in the $\mathrm{FeCl}_{3}$-induced mesenteric arteriole thrombosis models has been reported previously [66-68]. However, tail bleeding times did not differ significantly between the $\mathrm{mTOR}^{-1-}$ mice and WT mice (data not shown); the mechanism of this discrepancy is currently unknown, though the outcomes of tail injury models are known to be variable [69]. Therefore, much work needs to be done to increase our understanding of the detailed mechanisms of thrombus formation in vivo and in vitro and hemostasis.
Our results demonstrate that $\mathrm{mTOR}^{-1-}$ platelets show impaired thrombus formation when perfused on low-concentration collagen-coated surfaces, although $\mathrm{mTOR}^{-/-}$mice display normal hematopoietic parameters. The platelet counts were normal in the $\mathrm{mTOR}^{-1-}$ mice, which is similar to findings in Raptor ${ }^{-1-}$ mice [65], though the results differ in that mTOR deletion had no observable effect on the mean platelet volume (MPV), whereas Raptor $^{-1-}$ mice displayed a reduced MPV. The differences between these results may be explained by a combination of different mechanisms for the inhibition of mTOR in vivo, including a reduction in the translation activity and an increase in the lifespan [4, 70-74], or to the compensatory activation of PI3K signaling [75]. Other groups have also reported that $\mathrm{mTOR}^{\operatorname{loxp} / \text { loxp }} \mathrm{Mx} 1-\mathrm{Cre}^{+}\left(\mathrm{mTOR}^{-/-}\right)$[76] or Rosa26-CreERT2 ${ }^{+}$, TSC1 $1^{\text {loxp/loxp }}\left(\mathrm{TSC}^{-l-}\right)$ [77] mice are deficient in platelet production. The discrepancies may be explained by the differences in the conditional 
knockout models: normal platelet counts were observed for Raptor ${ }^{\mathrm{f} / \mathrm{fl}}$ CreER +TAM (Raptor-deficient) mice [71] and Raptor ${ }^{\mathrm{fl} / \mathrm{fl}} \mathrm{PF} 4-\mathrm{Cre}+\left(\mathrm{Raptor}^{-/-}\right)$[65], while other groups report that Raptor ${ }^{\text {loxp } / \text { loxp }} \mathrm{Mx1-Cre}{ }^{+}\left(\right.$Raptor $\left.^{-l-}\right)$ mice show deficient platelet production [78]. PF4-Cre mice were used to generate megakaryocyte/plateletspecific knockout mice [51], whereas Mx1-Cre was induced by polyinosinic-polycytidylic acid [79] and used to generate knockout cells during development, including hematopoietic stem cells [78]. Further work on the complex mechanisms of mTORC1 and mTORC2 may help to elucidate the role of mTOR at different stage of thrombopoiesis.

The dose-dependent deficiency in $\mathrm{mTOR}^{-1-}$ platelets during thrombus formation in vitro, particularly when grown on low-concentration collagen-coated surfaces, may be explained by platelet function (Additional file 1: Figure S9, as well as see Additional file 2).

Our results also demonstrate that isolated $\mathrm{mTOR}^{-1-}$ platelets display impaired thrombus formation after blood perfusion on micro-flow chambers which were coated with low-concentration fibrillar collagen. Consistently, GPVI- and PAR4-mediated aggregation was impaired in $\mathrm{mTOR}^{-1-}$ platelets upon activation with low concentrations of the agonists CRP and GYPGKF- $\mathrm{NH}_{2}$, while the aggregation level of $\mathrm{mTOR}^{-/-}$platelets that were induced by ADP was approximately consistent to that of WT platelets. No deficiency in aggregation was detected in $\mathrm{mTOR}^{-1-}$ platelets when higher doses of these agents were tested, which suggests that the phenotype of $\mathrm{mTOR}^{-1-}$ platelets is dose-dependent. Similar to our findings, Musumeci and colleagues showed a dose-dependent difference in DUSP3-deficient platelets: the platelet aggregation was impaired for low-dose CRPinduced DUSP3-deficient platelets, but no deficiency in aggregation was detected for higher dose CRP-induced DUSP3-deficient platelets [80]. Moreover, the levels of $\alpha_{\mathrm{IIb}} \beta_{3}$ activation were decreased in $\mathrm{mTOR}^{-/-}$platelets compared to WT platelets upon stimulation with low-dose GPVI-dependent collagen or PAR-dependent thrombin. However, there was almost no difference between the $\mathrm{mTOR}^{-1-}$ and WT platelets in the activation of $\alpha_{\mathrm{II}} \beta_{3}$ after stimulation with higher concentrations. Additionally, $\mathrm{mTOR}^{-1-}$ platelets displayed increased spreading while reducing clot retraction; however, this discrepancy in the literature may be explained by different molecular mechanisms between these processes [81-83] (see Additional file 1: Results and Discussion). However, future work is needed to pinpoint mTOR-regulated molecules in outside-in signaling. Our data also revealed that mTOR plays a negative role in regulating platelet spreading on collagen-coated surfaces, which is similar to the results of spreading on fibrinogen. These results suggest that mTOR may plays different roles in early and late outside-in signaling.

Platelets contain several types of secretory granules, most notably $\alpha$-granules, dense granules, and lysosomes. $\alpha$-granules contain P-selectin, fibrinogen, and other proteinaceous components; lysosomes contain proteolytic enzymes; and dense granules contain ATP, ADP, calcium, serotonin, and other molecules. Our results suggest that the regulation of dense granule secretion (ATP release) is an essential role of mTOR in platelets that are stimulated by GPVI agonists. This conclusion is based upon the following observations: (1) The expression of P-selectin was almost not influenced by mTOR deficiency in platelets after induction by agonists; (2) the defect in the aggregation of $\mathrm{mTOR}^{-1-}$ platelets induced by lower dose GPVI-dependent collagen was rescued by supplementation with ADP, while the aggregation of WT platelets induced by low-dose GPVI-dependent collagen was decreased to a level similar to that of mTOR-deficient platelets when apyrase was applied (data not shown); and (3) ADP restored the decreased phosphorylation of S6 Ser235/236, Akt Ser473, as well as the increased phosphorylation of PKC $\delta$ Thr505 and PKCe Ser729 in $\mathrm{mTOR}^{-/-}$platelets, although it is unclear why the phosphorylation levels of these molecules were not significantly increased in WT platelets after exogenous ADP was added (Additional file 1: Figure S7).

Our results demonstrate that the phosphorylation of Erk Thr202/Tyr204 was significantly decreased in mTORdeficient platelets or in WT platelets after treatment with the mTOR inhibitor, Torin1, when stimulated with GPVI/PARs agonist (data not shown). There is synergistic crosstalk between mTOR and MAPKs in other cell types [84]. For example, some studies observed MAPKs regulated mTOR (mTORC1) [63, 85, 86], while other studies found that mTOR (mTORC2) regulated MAPKs [87-89]. Interestingly, PKCs have been also been reported to be regulated by mTOR or mTORC2 in other cell types [4], and it is documented that MAPKs play important roles in regulation by PKCs in platelet activation [2]. Based on the literature mentioned above as well as our results, we hypothesize that mTOR or mTORC2 regulates Erk (possibly through PKCs).

Analysis of signaling molecules demonstrated that mTOR deficiency impaired the phosphorylation of S6 Ser235/236 and Akt Ser473 in platelets after low-dose $\mathrm{CRP} /$ collagen stimulation with GPVI. The phosphorylation of the S6 Ser235/236 and Akt Ser473 in mTOR $^{-1-}$ platelets was decreased to around $30 \%$ of that of WT platelets, and the phosphorylation of these substrates was ablated in some samples of $\mathrm{mTOR}^{-1-}$ platelets pre-incubated without apyrase. 
Moreover, a similar decrease in the phosphorylation of these downstream signaling molecules in response to low-dose collagen $(0.8 \mu \mathrm{g} / \mathrm{mL})$ was observed in WT platelets after treatment with the mTOR inhibitor Torin1, while almost no change was observed for $\mathrm{mTOR}^{-1-}$ platelets after the same treatment. As observed from the sample bands, Torin 1 may have exerted an effect on $\mathrm{mTOR}^{-1-}$ platelets regarding the phosphorylation of these downstream signaling molecules; however, there was no significant difference between $\mathrm{mTOR}^{-1-}$ platelets pre-incubated with Torin 1 and $\mathrm{mTOR}^{-1-}$ platelets pre-incubated without Torin1. Torin1 ablated the phosphorylation of S6/Akt Ser473 in WT platelets, which is similar to findings provided by Moore and colleagues [9]. A reason for these phenomena is that as a chemical inhibitor, Torin 1 also plays a nonspecific role on other kinases. For example, Torin1 exhibits a weaker influence on PI3K/ Akt [90]. We further confirmed the mTOR deficiency ablated phosphorylation of the substrates when apyrase was used to hydrolyze the released ADP. These findings occurred independently of substantive S6/Akt Ser473 phosphorylation in $\mathrm{mTOR}^{-/-}$platelets in the absence of exogenous apyrase. Additionally, exogenous ADP restored the decreased phosphorylation of S6 Ser235/236 and Akt Ser473 in $\mathrm{mTOR}^{-1-}$ platelets when stimulated with low-concentration GPVI agonist collagen. In addition, mTOR exerted almost no effect on ADP-induced platelet activation. Please see Additional file 1: Figure S7, S6 and Fig. 2c in order.

These results suggest that the released ADP activated $\mathrm{P}_{2} \mathrm{Ys}$, can bypass mTOR complexes and phosphorylate Akt Ser473 or S6 Ser235/236 (possibly through ERK [63, $72,73,75,85,86])$ in $\mathrm{mTOR}^{-1-}$ platelets when induced by low concentrations of GPVI-agonist/PAR4-agonist (PAR4 agonist GYPGKF- $\mathrm{NH}_{2}$ data not shown); these phosphorylation events can be amplified by an ADP secretion cascade. This may be the primary, or even the sole reason, why phosphorylation of the substrates is not typically ablated in $\mathrm{mTOR}^{-/-}$platelets when pre-incubated without apyrase. Interestingly, previous reports using blockers of ADP-receptor or apyrase have implicated that the direct activation of S6K1/S6 [10, 13, 91] and Akt Ser473 (as well as Erk, [92, 93]) by GPVI or PARs signaling mainly exists in normal platelets when stimulated with GPVI/PARs. In addition, it is well known that the ADP secretion induced by agonists and the subsequent activation of $\mathrm{P}_{2} \mathrm{Ys}$ would amplify phosphorylation signaling (including Akt Ser473, Erk) [2, 92, 94]. However, whether other molecules beyond ADP secretion-P2Ys are involved is unknown. These interesting phenomena as well as their mechanisms should be studied in future work.
These results also are consistent with the deficiency in mTOR signaling.

We further assessed the effect of mTOR deficiency on the phosphorylation of several PKC isoforms, which are classified by the structure of their regulatory domains. The expression of the $\mathrm{CPKC}$ (classical PKC) isoforms cPKC $\alpha$ and $\mathrm{cPKC} \beta$, and the $\mathrm{nPKC}$ (novel PKC) isoforms $\mathrm{nPKC} \delta$ and $\mathrm{nPKC} \theta$ have been observed in human platelets in many studies [33, 35, 36]. Additionally PKC $\mathrm{P}$ is expressed in human megakaryocytes but not in human platelets $[28,36,38]$, though mouse platelets also express PKC $\varepsilon[28,39]$. We therefore assessed the effects of CRP on each of these platelet-expressed PKCs. Our results demonstrate that the phosphorylation of both PKC $\delta$ and PKC $\varepsilon$ was enhanced after low-dose CRP stimulation. PKC enzymes have been proposed to regulate steps in the process of platelet activation, such as the mobilization of calcium ion, $\alpha_{\mathrm{IIb}} \beta_{3}$-mediated signaling; exocytosis or the secretion of granules; filopodia formation; and adhesion to the extracellular matrix $[20,23,25,29,33,35$, $36,95]$. Additionally, it has been suggested that cPKCs positively regulate platelet activation and thrombus formation, while the nPKC isoforms have been proposed to execute a negative regulatory role on platelet activation, at least in some cases $[24,96]$.

To verify the role of PKC $\delta$ in mTOR-dependent collagen response, we assessed the effects of the PKC $\delta$ inhibitor rottlerin. Our results demonstrate that rottlerin restored full aggregation and dense granule secretion (ATP release) of mTOR-deficient platelets in response to low-dose collagen. The selective PKC $\delta$ peptide inhibitor also restored the aggregation of $\mathrm{mTOR}^{-1-}$ platelets in response to low-dose collagen, and exerted smaller but similar role on the dense granule secretion of $\mathrm{mTOR}^{-/-}$ platelets. We also found that $\varepsilon V 1-2$ minimally rescued the aggregation of mTOR-deficient platelets in response to low-dose collagen. Given that PKCe has widely been reported to be a negative regulator of $\mathrm{ADP} / \mathrm{P} 2 \mathrm{Ys}$-mediated platelet activation [20,97], these results are consistent with current understanding of $\varepsilon V 1-2$ 's.

These results suggest that $\mathrm{PKC} \delta / \varepsilon$, especially $\mathrm{PKC} \delta$ but not $P K C \alpha / \beta$ and PKC $\theta$, may be involved in low-dose GPVI-mediated mTOR-dependent signaling (Additional file 1: Figure S9 as well as see Additional file 2).

\section{Conclusions}

In conclusion, we demonstrated that depending on the collagen concentration or extent of injury, mTOR functions as a positive regulator in thrombus formation in vitro when perfused on low-concentration collagencoated surfaces or in vivo after being subjected to less severe $\mathrm{FeCl}_{3}$-induced injury. mTOR was also found to 
exert a positive role in low-dose activation of GPVI in platelets in a dose-dependent manner, although the effect of mTOR deficiency was less dramatic, different experimental designs yielded similar results. Further work is required for a more complete understanding of the network of signaling mediators that are involved in this complex process.

\section{Supplementary Information}

The online version contains supplementary material available at https://doi. org/10.1186/s12967-021-02756-y.

Additional file 1. Additional Data SI, II

Additional file 2. Additional Information Part I

Additional file 3. Additional Information Part II \& II

\section{Acknowledgements}

We thank Dr. Yihua Wu for his help on designing experiments, and on analyzing/interpreting the data.

\section{Authors' contributions}

LW designed and performed the experiments, analyzed the data and wrote the manuscript; GL performed experiments, interpreted the data, and composed the manuscript; NW helped to generate the mTOR ${ }^{\mathrm{fl} / \mathrm{fl}} \mathrm{PF}$ $\mathrm{Cre}+\left(\mathrm{mTOR}^{-/-}\right)$mice, interpret the data, and composed the manuscript; $\mathrm{BD}$ helped with the aggregation experiments and the interpretation of data; $\mathrm{SH}$ performed experiments and interpreted the data; QL and FH helped with western blotting; ZC supplied the mice and assisted with mouse strain maintenance; WX assisted with the calculation of platelets and interpretation of the data; DX designed the study and wrote the manuscript; CG designed the study and compose the manuscript. All authors read and approved the final manuscript.

\section{Funding}

This work was supported by the National Natural Science Foundation of China $(81270586,81760653)$.

\section{Data availability statement}

The data used to support the findings of this study are available from the corresponding author upon request.

\section{Ethics approval and consent to participate}

All experiments were performed under the Guide for the Care and Use of Laboratory Animal (The National Academy Press, 2011) and were approved by the Board of Animal Study of Zhejiang University.

\section{Consent for publication}

The images and data contained in this manuscript are not related to a single individual and are entirely unidentifiable.

\section{Competing interests}

The authors declare no competing financial interests.

\section{Author details}

${ }^{1}$ Chronic Disease Research Institute, Department of Nutrition and Food Hygiene, Zhejiang University School of Public Health, 866 Yu-Hang-Tang Road, Hangzhou 310058, China. ${ }^{2}$ Department of Toxicology, Zhejiang University School of Public Health, 866 Yu-Hang-Tang Road, Hangzhou 310058, China. ${ }^{3}$ Department of Respiratory Medicine, Second Affiliated Hospital, Zhejiang University School of Medicine, 88 Jiefang Road, Hangzhou 310009, China. ${ }^{4}$ Zhejiang Hospital, 12 Lingyin Road, Hangzhou 310013, China. ${ }^{5}$ Department of Pharmacology, School of Basic Medical Sciences, Guizhou Medical University, Guiyang, Guizhou, China. ${ }^{6}$ Blood Research Institute, Blood Center of Wisconsin, Milwaukee, Milwaukee, WI 53201, USA.
Received: 19 November 2020 Accepted: 16 February 2021

Published online: 10 May 2021

\section{References}

1. Nieswandt B, Watson SP. Platelet-collagen interaction: is GPVI the central receptor? Blood. 2003;102:449-61.

2. Li Z, Delaney MK, O'Brien KA, Du X. Signaling during platelet adhesion and activation. Arterioscler Thromb Vasc Biol. 2010;30:2341-9.

3. Weyrich AS, Denis MM, Hansjorg S, Tolley ND, Jason F, Eliott S, Kraiss LW, Albertine KH, Mcintyre TM, Zimmerman GA. mTOR-dependent synthesis of $\mathrm{BCl}-3$ controls the retraction of fibrin clots by activated human platelets. Blood. 1975;2007:109.

4. Laplante M, Sabatini DM. mTOR signaling in growth control and disease. Cell. 2012;149:274-93.

5. Phung TL, Ziv K, Dabydeen D, Eyiah-Mensah G, Riveros M, Perruzzi C, Sun J, Monahan-Earley RA, Shiojima I, Nagy JA, et al. Pathological angiogenesis is induced by sustained Akt signaling and inhibited by rapamycin. Cancer Cell. 2006:10:159-70.

6. Sarbassov DD, Ali SM, Sengupta S, Sheen JH, Hsu PP, Bagley AF, Markhard $A L$, Sabatini DM. Prolonged rapamycin treatment inhibits mTORC2 assembly and Akt/PKB. Mol Cell. 2006;22:159-68.

7. Dobbelstein M, Moll U. Targeting tumour-supportive cellular machineries in anticancer drug development. Nat Rev Drug Discov. 2014;13:179-96.

8. Moschetta M, Reale A, Marasco C, Vacca A, Carratu MR. Therapeutic targeting of the mTOR-signalling pathway in cancer: benefits and limitations. Br J Pharmacol. 2014;171:3801-13.

9. Moore SF, Hunter RW, Hers I. mTORC2 protein complex-mediated Akt (Protein Kinase B) Serine 473 Phosphorylation is not required for Akt1 activity in human platelets [corrected]. J Biol Chem. 2011;286:24553-60.

10. Moore SF, Hunter RW, Hers I. Protein kinase C and P2Y12 take center stage in thrombin-mediated activation of mammalian target of rapamycin complex 1 in human platelets. J Thromb Haemost. 2014;12:748-60.

11. Wu Q, Huang KS, Chen M, Huang DJ. Rapamycin enhances platelet aggregation induced by adenosine diphosphate in vitro. Platelets. 2009:20:428-31.

12. Babinska A, Markell MS, Salifu MO, Akoad M, Ehrlich YH, Kornecki E. Enhancement of human platelet aggregation and secretion induced by rapamycin. Nephrol Dial Transplant. 1998;13:3153-9.

13. Aslan JE, Tormoen GW, Loren CP, Pang J, MCCarty OJ. S6K1 and mTOR regulate Rac1-driven platelet activation and aggregation. Blood. 2011;118:3129-36.

14. Gangloff YG, Mueller M, Dann SG, Svoboda P, Sticker M, Spetz JF, Um SH, Brown EJ, Cereghini S, Thomas G, Kozma SC. Disruption of the mouse mTOR gene leads to early postimplantation lethality and prohibits embryonic stem cell development. Mol Cell Biol. 2004;24:9508-16.

15. Holz MK, Ballif BA, Gygi SP, Blenis J. mTOR and S6K1 mediate assembly of the translation preinitiation complex through dynamic protein interchange and ordered phosphorylation events. Cell. 2005;123:569-80.

16. Sarbassov DD, Guertin DA, Ali SM, Sabatini DM. Phosphorylation and regulation of Akt/PKB by the rictor-mTOR complex. Science. 2005:307:1098-101.

17. Franco R, Martínez-Pinilla E, Navarro G, Zamarbide M. Potential of GPCRs to modulate MAPK and mTOR pathways in Alzheimer's disease. Prog Neurobiol. 2017;149-150:21-38.

18. Pal HC, Hunt KM, Diamond A, Elmets CA, Afaq F. Phytochemicals for the Management of Melanoma. Mini Rev Med Chem. 2016;16:953-79.

19. Buitrago L, Bhavanasi D, Dangelmaier C, Manne BK, Badolia R, Borgognone A, Tsygankov AY, McKenzie SE, Kunapuli SP. Tyrosine phosphorylation on spleen tyrosine kinase (Syk) is differentially regulated in human and murine platelets by protein kinase C isoforms. J Biol Chem. 2013;288:29160-9.

20. Bynagari-Settipalli YS, Lakhani P, Jin J, Bhavaraju K, Rico MC, Kim S, Woulfe D, Kunapuli SP. Protein kinase C isoform epsilon negatively regulates ADPinduced calcium mobilization and thromboxane generation in platelets. Arterioscler Thromb Vasc Biol. 2012;32:1211-9.

21. Chari R, Getz T, Nagy B Jr, Bhavaraju K, Mao Y, Bynagari YS, Murugappan S, Nakayama K, Kunapuli SP. Protein kinase C[delta] differentially regulates platelet functional responses. Arterioscler Thromb Vasc Biol. 2009;29:699-705. 
22. Chari R, Kim S, Murugappan S, Sanjay A, Daniel JL, Kunapuli SP. Lyn, PKCdelta, SHIP-1 interactions regulate GPVI-mediated platelet-dense granule secretion. Blood. 2009;1 14:3056-63.

23. Cohen $S$, Braiman A, Shubinsky G, Isakov N. Protein kinase C-theta in platelet activation. FEBS Lett. 2011;585:3208-15.

24. Harper MT, Poole AW. Diverse functions of protein kinase $\mathrm{C}$ isoforms in platelet activation and thrombus formation. J Thromb Haemost. 2010;8:454-62.

25. Konopatskaya O, Gilio K, Harper MT, Zhao Y, Cosemans JM, Karim ZA, Whiteheart SW, Molkentin JD, Verkade P, Watson SP, et al. PKCalpha regulates platelet granule secretion and thrombus formation in mice. J Clin Invest. 2009;119:399-407.

26. Konopatskaya O, Matthews SA, Harper MT, Gilio K, Cosemans JM, Williams CM, Navarro MN, Carter DA, Heemskerk JW, Leitges M, et al. Protein kinase $\mathrm{C}$ mediates platelet secretion and thrombus formation through protein kinase D2. Blood. 2011;118:416-24.

27. Moncada de la Rosa C, Radziwon-Balicka A, El-Sikhry H, Seubert J, Ruvolo PP, Radomski MW, Jurasz P. Pharmacologic protein kinase Calpha inhibition uncouples human platelet-stimulated angiogenesis from collageninduced aggregation. J Pharmacol Exp Ther. 2013;345:15-24.

28. Pears CJ, Thornber K, Auger JM, Hughes CE, Grygielska B, Protty MB, Pearce AC, Watson SP. Differential roles of the PKC novel isoforms, PKCdelta and PKCepsilon, in mouse and human platelets. PLoS ONE. 2008; $3:$ e3793.

29. Pula G, Schuh K, Nakayama K, Nakayama KI, Walter U, Poole AW. PKCdelta regulates collagen-induced platelet aggregation through inhibition of VASP-mediated filopodia formation. Blood. 2006;108:4035-44.

30. Unsworth AJ, Finney BA, Navarro-Nunez L, Severin S, Watson SP, Pears CJ. Protein kinase Cepsilon and protein kinase Ctheta double-deficient mice have a bleeding diathesis. J Thromb Haemost. 2012;10:1887-94.

31. Xiang B, Zhang G, Stefanini L, Bergmeier W, Gartner TK, Whiteheart SW, Li Z. The Src family kinases and protein kinase C synergize to mediate Gqdependent platelet activation. J Biol Chem. 2012;287:41277-87.

32. Karim ZA, Alshbool FZ, Vemana HP, Conlon C, Druey KM, Khasawneh FT. CXCL12 regulates platelet activation via the regulator of $\mathrm{G}$-protein signaling 16. Biochim Biophys Acta. 2016;1863:314-21.

33. Buensuceso CS, Obergfell A, Soriani A, Eto K, Kiosses WB, Arias-Salgado EG, Kawakami T, Shattil SJ. Regulation of outside-in signaling in platelets by integrin-associated protein kinase $\mathrm{C}$ beta. J Biol Chem. 2005:280:644-53.

34. Soriani A, Moran BVM, Kawakami T, Altman A, Lowell C, Eto K, Shattil SJ. A role for PKCtheta in outside-in alpha(IIb)beta3 signaling. J Thromb Haemost. 2006;4:648-55.

35. Swaminathan Murugappan FT, Robert T. Dorsam, Haripriya Shankar, Kunapuli aSP: differential role of protein kinase $C$ delta isoform in agonistinduced dense granule secretion in human platelets. J Biol Chem. 2004;279:2360-7.

36. Cohen S, Braiman A, Shubinsky G, Ohayon A, Altman A, Isakov N. PKCtheta is required for hemostasis and positive regulation of thrombininduced platelet aggregation and alpha-granule secretion. Biochem Biophys Res Commun. 2009;385:22-7.

37. Bynagari YS, Nagy B Jr, Tuluc F, Bhavaraju K, Kim S, Vijayan KV, Kunapuli SP. Mechanism of activation and functional role of protein kinase Ceta in human platelets. J Biol Chem. 2009;284:13413-21.

38. Gobbi G, Mirandola P, Sponzilli I, Micheloni C, Malinverno C, Cocco L, Vitale M. Timing and expression level of protein kinase $C$ epsilon regulate the megakaryocytic differentiation of human CD34 cells. Stem Cells. 2007:25:2322-9.

39. Hall KJ, Harper MT, Gilio K, Cosemans JM, Heemskerk JW, Poole AW. Genetic analysis of the role of protein kinase Ctheta in platelet function and thrombus formation. PLOS ONE. 2008;3:e3277.

40. Xu ZB, Chaudhary D, Olland S, Wolfrom S, Czerwinski R, Malakian K, Lin L, Stahl ML, Joseph-McCarthy D, Benander C, et al. Catalytic domain crystal structure of protein kinase C-theta (PKCtheta). J Biol Chem. 2004:279:50401-9.

41. Nagy B, Bhavaraju K, Getz T, Bynagari YS, Kim S, Kunapuli SP. Impaired activation of platelets lacking protein kinase $C-\theta$ isoform. Blood. 2009:113:2557-67.

42. Steinberg SF. Structural basis of protein kinase $\mathrm{C}$ isoform function. Physiol Rev. 2008;88:1341-78.
43. Morton LF, Hargreaves PG, Farndale RW, Young RD, Barnes MJ. Integrin alpha 2 beta 1 -independent activation of platelets by simple collagenlike peptides: collagen tertiary (triple-helical) and quaternary (polymeric) structures are sufficient alone for alpha 2 beta 1 -independent platelet reactivity. Biochem J. 1995;306(Pt 2):337-44.

44. Chen L, Hahn H, Wu G, Chen CH, Liron T, Schechtman D, Cavallaro G, Banci L, Guo Y, Bolli R. Opposing cardioprotective actions and parallel hypertrophic effects of delta PKC and epsilon PKC. Proc Natl Acad Sci USA. 2001;98:11114-9.

45. Dorn GW, Souroujon MC, Liron T, Chen CH, Gray MO, Zhou HZ, Csukai M, Wu G, Lorenz JN, Mochly-Rosen D. Sustained in vivo cardiac protection by a rationally designed peptide that causes epsilon protein kinase C translocation. Proc Natl Acad Sci U S A. 1999;96:12798-803.

46. Johnson JA, Gray MO, Chen C-H, Mochly-Rosen D. A protein kinase C translocation inhibitor as an isozyme-selective antagonist of cardiac function. J Biol Chem. 1996;271:24962-6.

47. Koyanagi T, Noguchi K, Ootani A, Inagaki K, Robbins RC, Mochly-Rosen D. Pharmacological inhibition of epsilon PKC suppresses chronic inflammation in murine cardiac transplantation model. J Mol Cell Cardiol. 2007:43:517-22.

48. Sweitzer SM, Wong SM, Peters MC, Mochly-Rosen D, Yeomans DC, Kendig JJ. Protein kinase C epsilon and gamma: involvement in formalin-induced nociception in neonatal rats. J Pharmacol Exp Ther. 2004;309:616.

49. Schwarze SR, Ho A, Vocero-Akbani A, Dowdy SF. In vivo protein transduction: delivery of a biologically active protein into the mouse. Science. 1999;285:1569-72.

50. Risson V, Mazelin L, Roceri M, Sanchez H, Moncollin V, Corneloup C, Richard-Bulteau H, Vignaud A, Baas D, Defour A, et al. Muscle inactivation of mTOR causes metabolic and dystrophin defects leading to severe myopathy. J Cell Biol. 2009;187:859-74.

51. Ralph T, Tibor S, Hui HS, Skoda RC. Pf4-Cre transgenic mice allow the generation of lineage-restricted gene knockouts for studying megakaryocyte and platelet function in vivo. Blood. 2007;109:1503-6.

52. Gao C, Boylan B, Fang J, Wilcox DA, Newman DK, Newman PJ. Heparin promotes platelet responsiveness by potentiating alphallbbeta3-mediated outside-in signaling. Blood. 2011;117:4946-52.

53. Dai B, Wu P, Xue F, Yang R, Yu Z, Dai K, Ruan C, Liu G, Newman PJ, Gao C. Integrin-alphallbbeta3-mediated outside-in signalling activates a negative feedback pathway to suppress platelet activation. Thromb Haemost. 2016;116:918-30.

54. Khatlani T, Pradhan S, Da Q, Gushiken FC, Bergeron AL, Langlois KW, Molkentin JD, Rumbaut RE, Vijayan KV. The $\beta$ isoform of the catalytic subunit of protein phosphatase $2 \mathrm{~B}$ restrains platelet function by suppressing outside-in allb $\beta 3$ integrin signaling. J Thromb Haemost. 2015:12:2089-101.

55. Garcia A, Kim S, Bhavaraju K, Schoenwaelder SM, Kunapuli SP. Role of phosphoinositide 3-kinase beta in platelet aggregation and thromboxane A2 generation mediated by Gi signalling pathways. Biochem J. 2010;429:369-77.

56. Conant CG, Nevill JT, Zhou Z, Dong JF, Schwartz MA, lonescu-Zanetti C. Using well-plate microfluidic devices to conduct shear-based thrombosis assays. J Lab Autom. 2011;16:148-52.

57. Hughes CE, Finney BA, Koentgen F, Lowe KL, Watson SP. The N-terminal SH2 domain of Syk is required for (hem)ITAM, but not integrin, signaling in mouse platelets. Blood. 2015;125:144-54.

58. Daria MR, Kanad D, Grimes KV. Protein kinase C, an elusive therapeutic target? Nat Rev Drug Discov. 2012;11:937-57.

59. Way KJ, Chou E, King GL. Identification of PKC-isoform-specific biological actions using pharmacological approaches. Trends Pharmacol Sci. 2000;21:181-7.

60. Xiao G-Q, Qu Y, Sun Z-Q, Mochly-Rosen D, Boutjdir M. Evidence for functional role of $\varepsilon$ PKC isozyme in the regulation of cardiac $\mathrm{Na}+$ channels. Am J Physiol Cell Physiol. 2001:281:C1477-86.

61. Pan CJ, Tang JJ, Weng YJ, Wang J, Huang N. Preparation and characterization of rapamycin-loaded PLGA coating stent. J Mater Sci Mater Med. 2007;18:2193-8.

62. Shuchman M. Trading restenosis for thrombosis? New questions about drug-eluting stents. N Engl J Med. 2006;355:1949-52. 
63. Mukhopadhyay NK, Price DJ, Kyriakis JM, Pelech S, Sanghera J, Avruch J. An array of insulin-activated, proline-directed serine/threonine protein kinases phosphorylate the p70 S6 kinase. J Biol Chem. 1992;267:3325-35.

64. Raslova H, Baccini V, Loussaief L, Comba B, Larghero J, Debili N, Vainchenker W. Mammalian target of rapamycin (mTOR) regulates both proliferation of megakaryocyte progenitors and late stages of megakaryocyte differentiation. Blood. 2006;107:2303-10.

65. Yang J, Zhou X, Fan X, Xiao M, Yang D, Liang B, Dai M, Shan L, Lu J, Lin Z. mTORC1 promotes aging-related venous thrombosis in mice via elevation of platelet volume and activation. Blood. 2016;128:615-24.

66. Furie BFB. In vivo thrombus formation. J Thromb Haemost. 2007;5:12-7.

67. Tseng MT, Dozier A, Haribabu B, Graham UM. Transendothelial migration of ferric ion in FeCl3 injured murine common carotid artery. Thromb Res. 2006;118:275-80.

68. Eckly A, Hechler B, Freund M, Zerr M, Cazenave JP, Lanza F, Mangin PH, Gachet C. Mechanisms underlying FeCl3-induced arterial thrombosis. J Thromb Haemost. 2011;9:779-89.

69. Greene TK, Schiviz A, HoellriegI W, Poncz M, Muchitsch EM. Animal models subcommittee of the $\mathrm{S}$, standardization committee of the I: towards a standardization of the murine tail bleeding model. J Thromb Haemost. 2010;8:2820-2.

70. Santini E, Heiman M, Greengard P, Valjent E, Fisone G. Inhibition of mTOR signaling in Parkinson's disease prevents L-DOPA-induced dyskinesia. Sci Signal. 2009;2:ra36.

71. Santini E, Alcacer C, Cacciatore S, Heiman M, Herve D, Greengard P, Girault JA, Valjent E, Fisone G. L-DOPA activates ERK signaling and phosphorylates histone $\mathrm{H} 3$ in the striatonigral medium spiny neurons of hemiparkinsonian mice. J Neurochem. 2009;108:621-33.

72. Pullen N. Phosphorylation and activation of p70s6k by PDK1. Science. 1998;279:707-10.

73. Roux PP, Shahbazian D, Vu H, Holz MK, Cohen MS, Taunton J, Sonenberg $\mathrm{N}$, Blenis J. RAS/ERK signaling promotes site-specific ribosomal protein S6 phosphorylation via RSK and stimulates cap-dependent translation. J Biol Chem. 2007;282:14056-64.

74. Selman CTJ, Wieser D, Irvine E, Lingard SJ, Choudhury Al, Claret M, AlQassab H, Carmignac D, Ramadani F, Woods A, Robinson IC, Schuster E, Batterham RL, Kozma SC, Thomas G, Carling D, Okkenhaug K, Thornton JM, Partridge L, Gems D, Withers DJ. Ribosomal protein S6 kinase 1 signaling regulates mammalian life span. Science. 2009;326:140-4.

75. Dennis PB, Pullen N, Pearson RB, Kozma SC, Thomas G. Phosphorylation sites in the autoinhibitory domain participate in p70(s6k) activation loop phosphorylation. J Biol Chem. 1998:273:14845-52.

76. Guo F, Zhang S, Grogg M, Cancelas JA, Varney ME, Starczynowski DT, Du W, Yang JQ, Liu W, Thomas G, et al. Mouse gene targeting reveals an essential role of mTOR in hematopoietic stem cell engraftment and hematopoiesis. Haematologica. 2013;98:1353-8.

77. Gan B, Sahin E, Jiang S, Sanchezaguilera A, Scott KL, Chin L, Williams DA, Kwiatkowski DJ, Depinho RA. mTORC1-dependent and-independent regulation of stem cell renewal, differentiation, and mobilization. Proc Natl Acad Sci USA. 2008;105:19384-9.

78. Kalaitzidis D, Sykes Stephen M, Wang Z, Punt N, Tang Y, Ragu C, Sinha Amit U, Lane Steven W, Souza Amanda L, Clish Clary B, et al. mTOR complex 1 plays critical roles in hematopoiesis and pten-loss-evoked leukemogenesis. Cell Stem Cell. 2012;11:429-39.

79. Kuhn R, Schwenk F, Aguet M, Rajewsky K. Inducible gene targeting in mice. Science. 1995;269:1427-9.

80. Musumeci L, Kuijpers MJ, Gilio K, Hego A, Theatre E, Maurissen L, Vandereyken M, Diogo CV, Lecut C, Guilmain W, et al. Dual-specificity phosphatase 3 deficiency or inhibition limits platelet activation and arterial thrombosis. Circulation. 2015;131:656-68

81. Flevaris P, Stojanovic A, Gong H, Chishti A, Welch E, Du X. A molecular switch that controls cell spreading and retraction. J Cell Biol. 2007; 179:553-65.

82. Gong H, Shen B, Flevaris P, Chow C, Lam SC, Voyno-Yasenetskaya TA, Kozasa T, Du X. G protein subunit Galpha13 binds to integrin alphallbbeta3 and mediates integrin "outside-in" signaling. Science. 2010;327:340-3.

83. Shen B, Zhao X, O'Brien KA, Stojanovic-Terpo A, Delaney MK, Kim K, Cho J, Lam SC, Du X. A directional switch of integrin signalling and a new antithrombotic strategy. Nature. 2013;503:131-5.
84. Pernice HF, Schieweck R, Kiebler MA, Popper B. mTOR and MAPK: from localized translation control to epilepsy. Bmc Neurosci. 2016;17:73.

85. Gangarossa G, Perroy J, Valjent E. Combinatorial topography and cell-type specific regulation of the ERK pathway by dopaminergic agonists in the mouse striatum. Brain Struct Funct. 2013;218:405-19.

86. Gobert D, Topolnik L, Azzi M, Huang L, Badeaux F, Desgroseillers L, Sossin WS, Lacaille JC. Forskolin induction of late-LTP and up-regulation of $5^{\prime}$ TOP mRNAs translation via mTOR, ERK, and PI3K in hippocampal pyramidal cells. J Neurochem. 2008;106:1160-74.

87. Chen XG, Liu F, Song XF, Wang ZH, Dong ZQ, Hu ZQ, Lan RZ, Guan W, Zhou TG, Xu XM, Lei H. Rapamycin regulates Akt and ERK phosphorylation through mTORC1 and mTORC2 signaling pathways. Mol Carcinogen. 2010;49:603-10.

88. Edwards BS, Isom WJ, Navratil AM. Gonadotropin releasing hormone activation of the mTORC2/Rictor complex regulates actin remodeling and ERK activity in LbetaT2 cells. Mol Cell Endocrinol. 2016;439:346-53.

89. Jindra PT, Jin YP, Jacamo R, Rozengurt E, Reed EF. MHC class I and integrin ligation induce ERK activation via an mTORC2-dependent pathway. Biochem Biophys Res Commun. 2008;369:781-7.

90. Qingsong L, Jae Won C, Jinhua W, Kang SA, Thoreen CC, Andrew M, Wooyoung H, Jianming Z, Taebo S, Sabatini DM. Discovery of 1-(4-(4-propionylpiperazin-1-yl)-3-(trifluoromethyl)phenyl)-9-(quinolin-3-yl)benzo[h] $[1,6]$ naphthyridin-2(1H)-one as a highly potent, selective mammalian target of rapamycin (mTOR) inhibitor for the treatment of cancer. J Med Chem. 2010;53:7146-55.

91. Aslan JE, Mccarty OJT. Regulation of the mTOR-Rac1 axis in platelet function. Small Gtpases. 2012;3:67-70.

92. Moroi AJ, Watson SP. Impact of the PI3-kinase/Akt pathway on ITAM and hemITAM receptors: haemostasis, platelet activation and antithrombotic therapy. Biochem Pharmacol. 2015;94:186-94.

93. Yue M, Luo D, Yu S, Liu P, Zhou Q, Hu M, Liu Y, Wang S, Huang Q, Niu Y, et al. Misshapen/NIK-related kinase (MINK1) is involved in platelet function, hemostasis, and thrombus formation. Blood. 2016;127:927-37.

94. Vilahur G, Gutiérrez M, Arzanauskaite M, Mendieta G, Ben-Aicha S, Badimon L. Intracellular platelet signalling as a target for drug development. Vascul Pharmacol. 2018;111:22-5

95. Haimovich BKN, Ji P. Protein kinase C regulates tyrosine phosphorylation of pp125FAK in platelets adherent to fibrinogen. Blood. 1996;87:152-61.

96. Gilio K, Harper MT, Cosemans JM, Konopatskaya O, Munnix IC, Prinzen L, Leitges M, Liu Q, Molkentin JD, Heemskerk JW, Poole AW. Functional divergence of platelet protein kinase C (PKC) isoforms in thrombus formation on collagen. J Biol Chem. 2010;285:23410-9.

97. Unsworth AJ, Smith H, Gissen P, Watson SP, Pears CJ. Submaximal inhibition of protein kinase $C$ restores $A D P$-induced dense granule secretion in platelets in the presence of Ca2+. J Biol Chem. 2011;286:21073-82.

\section{Publisher's Note}

Springer Nature remains neutral with regard to jurisdictional claims in published maps and institutional affiliations.
Ready to submit your research? Choose BMC and benefit from:

- fast, convenient online submission

- thorough peer review by experienced researchers in your field

- rapid publication on acceptance

- support for research data, including large and complex data types

- gold Open Access which fosters wider collaboration and increased citations

- maximum visibility for your research: over $100 \mathrm{M}$ website views per year

At $\mathrm{BMC}$, research is always in progress.

Learn more biomedcentral.com/submissions 